УДК 663.1

\title{
МЕТОДЫ ПОДГОТОВКИ РАСТИТЕЛЬНОГО СЫРЬЯ К БИОКОНВЕРСИИ В КОРМОВЫЕ ПРОДУКТЫ И БИОЭТАНОЛ
}

\author{
(ㄱ) В.И. Суикова ${ }^{I *}$, Л.В. Устюжанинова ${ }^{2}$, О.В. Березина ${ }^{I}$, С.В. Яроцкий \\ ${ }^{1}$ Государственный научно-исследовательский институт генетики \\ и селекции промышленных микроорганизмов, 1-й Дорожный проезд, 1, \\ Москва, 117545 (Россия), e-mail: sushkovaval@mail.ru \\ ${ }^{2}$ Вятский государственный университет, ул. Московская, 36, Киров, 610000 \\ (Россия)
}

Представлен анализ литературных данных следующих способов предобработки крахмал-, пентозан- и целлюлозосодержащего растительного сырья к ферментативному гидролизу (ФГ) полисахаридов (ПС): гидротермических, органосольвентных с получением технической целлюлозы, органосольвентных с серной кислотой, кислотно-катализированных с паровым взрывом, щелочных, бисульфитного (SPORL) и кислотно-каталитического с использованием дисковой мельницы.

На основании анализа даны рекомендации по совершенствованию технологической схемы получения кормовых белковых продуктов из отрубей совместно с другими зерноотходами. Технологическая схема должна включать дополнительный процесс тонкого измельчения отрубей и зерноотходов и гидротермодинамическую обработку (ГТДО) при следующем технологическом режиме: а.с.в. не менее $15 \% ; 86-100{ }^{\circ} \mathrm{C}$, время выдержки при этой температуре не более 1 ч с термостабильным ферментным препаратом, содержащим $\alpha$-амилазу (Зимаджунт 340С*, или Амилаза НТ4000, или Амилекс 4T). Эффективность последующего ФГ частично гидролизованного крахмала и некрахмалистых полисахаридов крахмалсодержащего сырья обеспечивает следующий комплекс ферментных препаратов: глюковамарин, GC 220, обладающий целлюлазной, целлобиазной, ксиланазной и $\beta$-глюканазной активностями и Novozymes 188 , содержащий целлобиазу.

Подтверждены данные по наиболее эффективным методам предподготовки пентозан- и целлюлозосодержащего растительного сырья к ферментативному гидролизу целлюлозы в $2 \%$ суспензии лигноцеллюлозного остатка, позволяющими получить общий выход сахаров и выход этанола не менее $90 \%$ от теоретического, как с делигнификацией, так и без отделения лигнина. Перспективными из них можно считать следующие: органосольвентный с $\mathrm{H}_{2} \mathrm{SO}_{4}$, паровой взрыв с $\mathrm{SO}_{2}$ и последующей промывкой экструдированной биомассы водой и окислительно-щелочным раствором и механохимические: бисульфитный (SPORL) и кислотно-каталитический с использованием установок горячего размола (УГР). Установлено, что в первых двух способах допускается содержание лигнина в лигноцеллюлозном остатке до 16-18\%, а в третьем до 30\%. Кислотно-каталитический метод гидролиза с элементами технологии SPORL c использованием установок горячего размола (УГР) рекомендован к лабораторным и опытно-промышленным испытаниям в гидролизной промышленности России.

Эффективность ФГ целлюлозы из лигноцеллюлозного остатка обеспечивают следующие комплексы ферментных препаратов: Celluclast (20 FPU/г глюкана), и Novozyme188 (соотношение $\beta$-глюкозидазы к целлюлазе 1,75-2,0 : 1) или Spezyme CP, GC-220 (15 FPU/г глюкана), Multifect Xylanase (соотношение $\beta$-глюкозидазы к целлюлазе 2,0 : 1).

Ключевые слова: крахмалсодержащее сырье, зерноотходы, пентозан- и целлюлозосодержащее сырье, полисахариды, гемицеллюлозы, гемицеллюлозный гидролизат, лигноцеллюлозный остаток, ферментативный гидролиз, ферментный препарат; амилазная, целлюлазная, ксиланазная активности; степень конверсии, выход продукта, сырой протеин, стадии технологической схемы, материальный баланс.

Сушкова Валентина Ивановна - доктор биологических наук, ведущий научный сотрудник,

e-mail: sushkovaval@mail.ru

Устюжанинова Людмила Васильевна - инженер,

e-mail: ujilucy9i@gmail.com

Березина Оксана Валентиновна - кандидат

биологических наук, старший научный сотрудник,

e-mail: sushkovaval@mail.ru

Ярочкий Сергей Викторович - доктор биологических

наук, заведующий лабораторией,

e-mail: yarotsky@genetika.ru
Работа выполнена при поддержке Министерства образования и науки РФ в рамках проекта ЕврАзЭС №14.M04.12.0007 от 27 июня 2014 г.

\section{Введение}

Для получения продуктов биоконверсии, в частности микробного кормового белка, биоэтанола и других, чаще всего используют возобновляемое углеводсодержащее сырье. Источником углеводсо-

\footnotetext{
* Автор, с которым следует вести переписку.
} 
держащего сырья как наиболее дешевого являются отходы производств, перерабатывающих растительное сырье. В результате перехода на рыночные отношения многие биохимические предприятия по производству кормовых дрожжей из нейтрализованных гидролизатов растительного сырья прекратили свое существование, другие сократили объемы их производства в связи с переходом на производство биоэтанола. В результате производство сельскохозяйственных животных и птиц испытывает недостаток в кормах и кормовом белке собственного производства. Согласно поставленной президентом России задаче по обеспечению собственным продовольствием на 80-90\% дефицит кормовых продуктов может составить не менее 1 млн т.

В связи с этим особенно остро стоит вопрос о развитии производства кормовых белковых добавок. Кормовые белковые смеси, состоящие из кормовых дрожжей и кормового белкового продукта из отрубей, сегодня производят ООО «Базовый корм» (Брянская обл.), ПАО «Волжский гидролизно-дрожжевой завод» (Республика Марий Эл) и др. Данную кормовую смесь реализуют на рынках России и Западной Европы. Производимая в России кормовая смесь имеет сырой протеин не менее 46,3\% вес. (ТУ 9296-002-863254152012). Этот показатель выше, чем в шротах подсолнечном и соевом (38-42 и 43-45\% вес. соответственно) за счет смешения с кормовыми дрожжами (47-50\% вес.). Одна из причин низкого сырого протеина в кормовой белковой добавке из отрубей - небольшое содержание в них углеводов (25-42\% вес). Поэтому получить высокий показатель белка сложно. Повышение конкурентоспособности кормовой белковой добавки из отрубей может быть достигнуто за счет решения следующих основных задач:

- разработка эффективной и более дешевой технологии подготовки зерноотходов к ферментативному гидролизу (ФГ) полисахаридов (ПС);

- использование отходов с содержанием углеводов более 42;

- подбор комплекса наиболее активных ферментных препаратов для ФГ всех углеводных компонентов сырья.

Перспектива развития производства биоэтанола из лигноцеллюлозного сырья, и в частности из древесины, лежит в области его использования как альтернативного жидкого биотоплива. Основным преимуществом использования биоэтанола в качестве топлива или высокооктановой добавки к нефтяному топливу является то, что снижается концентрация сажи, окислов азота, серы в выхлопных газах автомашин. Это имеет особенное значение для мегаполисов, где воздушная среда загрязнена выхлопными газами автомашин, и в результате имеет место высокая заболеваемость аллергией жителей мегаполисов. Это также может уменьшить эффект глобального потепления, что, возможно, является причиной повышения респираторных болезней у людей.

Но сегодня технический биоэтанол в России неконкурентоспособен на рынке жидкого топлива по причине высокой себестоимости. Необходимо снижение его себестоимости за счет совершенствования процесса гидролиза древесиной щепы и создание экономически эффективного и экологически чистого гидролизного производства.

Экономическая эффективность производства биоэтанола в основном зависит от вида используемого сырья, технологий процессов подготовки его к биоконверсии ее и условий.

Известны сравнительные экономические расчеты себестоимости биоэтанола из зерна и древесины (производственные данные) [1]. В структуре себестоимости этанола из зерна расходы на зерно и ферментные препараты составляют 62-70\%. В гидролизном производстве этанола из отходов от переработки древесины затраты на сырье - около $12 \%$ от его себестоимости. Высокий процент расходов на сырье в первом случае можно объяснить низким расходом теплоэнергоресурсов, а также высокими затратами на ферментные препараты - 5\% от полной себестоимости. Высокий процент расходов на сырье в первом случае можно объяснить низким расходом теплоэнергоресурсов, а также высокими затратами на ферментные препараты $-5 \%$ от полной себестоимости. Во втором случае наибольшие затраты составляют теплоэнергоресурсы - $40 \%$ и постоянные расходы около $40 \%$ [1].

В производстве технического биоэтанола основным потребителем теплоэнергоресурсов является процесс сернокислотного гидролиза древесной щепы - процесс перколяционного гидролиза. Несмотря на положительные стороны этого процесса, он имеет ряд существенных недостатков. Первое - высокий гидромодуль (13-16), не позволяющий получать концентрированные растворы моносахаридов в гидролизате (при переработке хвойной древесины $\mathrm{PB}=2,5-2,9 \%$ из них гексоз - 72-84\%) и этанола в спиртовой бражке. Это вызывает высокий расход теплоэнергоресурсов при выделении этанола и образование жидких отходов. Второе сернокислотный гидролиз целлюлозы осуществляют при постепенном повышении температуры от 150 до 
$180{ }^{\circ} \mathrm{C}$, что также сопровождается высоким расходом теплоэнергоресурсов. Третье - низкий выход сахаров редуцирующих веществ (выход $\mathrm{PB}=35-42 \%$ от а.с.с. или 53-65\% от полисахаридов в сырье) из-за распада моносахаридов; и низкая биологическая доброкачественность гидролизата (биологическую доброкачественность оценивают по редуцирующим примесям - разница между количеством редуцирующих веществ и суммой моносахаридов (7-14\%) [2]). Поэтому первостепенной задачей гидролизной промышленности является замена метода перколяционного гидролиза на способ, не имеющий данных недостатков.

Ученые всех стран пришли к единому мнению, что процесс ФГ целлюлозы не имеет данных недостатков. Основное преимущество ФГ ПС заключается в том, что его проводят при низких температурах, это позволяет экономить теплоэнергоресурсы и получать биологически доброкачественные субстраты для процессов ферментации, что способствует повышению выхода целевых продуктов. Это особенно важно в случае переработки концентрированных субстратов.

Исследования по получению биоэтанола из растительного сырья так же, как и кормовых продуктов, направлены на разработку более эффективных и дешевых способов подготовки сырья к ФГ ПС. В настоящее время проведено достаточное количество исследований по различным процессам конверсии биомассы древесины и подготовки ее к ФГ целлюлозы. Поэтому назрела необходимость рассмотрения данных исследований с целью определения наиболее экономически эффективных процессов.

В данной работе использован обзор по конверсии биомассы древесины, составленный на основании 123 научных источников, из которых более 50 - иностранные источники [3].

Цель данной работы - на основании литературных данных выработать рекомендации для производства технического биоэтанола, при этом надо решить следующие задачи:

- определить оптимальную, экономически выгодную степень измельчения сырья;

- выбрать экономически эффективный метод предобработки измельченного древесного сырья к ФГ целлюлозы, заключающийся в деструкции лигноуглеводных связей, разрушении кристаллической структуры целлюлозы, разделении основных компонентов сырья (гемицеллюлозы, целлюлоза, лигнин) и получения гидролизата гемицеллюлоз (ГЦ), лигнина и лигноцеллюлозного остатка;

- для снижения затрат в рассмотренных процессах предподготовки лигноцеллюлозного сырья к эффективному ФГ целлюлозы установить оптимальное остаточное содержание лигнина в лигноцеллюлозном остатке.

Решение данных задач позволит обеспечить конкурентоспособность производства биоэтанола из отходов производств, перерабатывающих лигноцеллюлозное сырье, на рынке жидкого топлива.

Выбор способа предобработки растительного сырья и комплекса ФП зависит от химического состава биомассы растений. Углеводсодержащее сырье растительного происхождения по химическому составу подразделяют на сахар-, крахмал-, пентозан- и целлюлозосодержащие. В данной работе рассматривается конверсия трех последних видов растительной биомассы.

\section{Химический состав растительного сырья}

Для подготовки крахмалсодержащего сырья (зерносырье и др.) к ФГ достаточно его измельчить (фракция с $\mathrm{d}<1$ мм) и провести гидротермическую обработку. Сложность химического состава и жесткость структуры биомассы пентозан- и целлюлозосодержащего сырья усложняет проведение процессов гидролиза ПС до моносахаридов. Если гидролиз с химическими реагентами позволяет гидролизовать ПС биомассы данных видов сырья при последовательном повышении температуры процесса, то для ФГ различных ПС растительного сырья необходимо подбирать способ предобработки и свой комплекс ФП.

Предобработка пентозан- и целлюлозосодержащего сырья к ФГ заключается в деструкции лигноуглеводных связей в лигнин-гемицеллюлозной матрице, в которую заключены микрофибрилы целлюлозы, разрушении кристаллической структуры целлюлозы, разделении основных компонентов сырья (гемицеллюлозы, целлюлоза, лигнин) и выделении лигнина. Поэтому в данном случае используют комплексные механические и термохимические методы [2, 5-7]. Выбор способа и технологических режимов предобработки зависят от вида сырья, т.е. от содержания, состава, структуры и молекулярной массы пентозанов и лигнина, степени кристалличности целлюлозы в растительной биомассе.

Так как пентозы менее устойчивы к распаду, а также пентозансодержащее сырье и однолетнее растительное сырье содержат меньше лигнина, то способы и технологические режимы предобработки для них должны быть менее интенсивными, более мягкими. Хвойная древесина России содержит 24-30\% лигнина, 
пентозансодержащее сырье, такое как лиственная древесина - 19-29\%, однолетнее с/х сырье, в том числе кукурузная кочерыжка - 14,5-18,6\% и пшеничная солома - 16-24,5\% [2, 5-7].

Химический состав ПС различных видов растительного сырья достаточно исследован и представлен в известной литературе [2, 5-7].

Целлюлоза - линейный гомополисахарид, молекула ее состоит из однородных остатков глюкопиранозы, а это упрощает проведение ее ФГ после отделения остальных компонентов сырья. Для разных видов сырья целлюлоза отличается молекулярной массой, размерами микрофибрилл и разной степенью упорядоченности молекул, т.е. степенью кристалличности. Это влияет на выбор способа предобработки сырья.

Гемицеллюлозы (ГЦ) имеют более сложный и разнообразный химический состав и структуру в зависимости от вида сырья. В.И. Шарков [6] выделил три основные группы в зависимости от содержания ГЦ в биомассе растительного сырья: хвойной древесины, лиственной древесины и однолетних растений. Относительное содержание компонентов в ГЦ растительных тканей представлено на рисунке.

По данным рисунка можно сделать выводы, что ПС ГЦ являются в основном:

- глюкоманнаны и галактоглюкоманнаны для биомассы хвойных растений;

- ксиланы для биомассы лиственных растений;

- арабогалактаны и ксиланы для биомассы однолетних растений.

Если содержание данных компонентов в древесине различных видов различается на $1-4 \%$, то для однолетних растений разница составляет от 3 до $12 \%$ и для ПС, содержащих ксилозу, разница достигает $17 \%$ в сторону меньших значений. Это также может влиять на выбор способа предобработки сырья и технологического режима.

ГЦ в одном виде растительного сырья не однородны по своему составу и структуре. ГЦ состоят из трех фракций, которые различаются также по степени гидролизуемости. Первая и вторая фракции являются легкогидролизуемыми, причем первая фракции гидролизуется быстрее. Соотношения первой и второй фракций для различных видов растительного сырья различаются, и в каждом отдельном случае их надо устанавливать экспериментально. Например, для древесины ели легкогидролизуемые фракции гемицеллюлоз составляют 40 и $60 \%$ соответственно от их общего содержания, а для кукурузной кочерыжки это соотношение составляет 80 и 20\% [4, 8]. Третья фракция ГЦ заключена между макромолекулами целлюлозы и гидролизуется вместе с ней.

Кроме того, ГЦ, как правило, являются разветвленными гетерополисахаридами. По этим причинам подобрать ФП для их ФГ с одним или несколькими ферментами затруднительно. Известны следующие два пути гидролиза ГЦ: 1) полный гидролиз до моносахаров химическими реагентами; 2) ФГ только основного ПС ксилана или пектина с частичным гидролизом их и с получением раствора олигосахаров и моносахаров. Для крахмалсодержащего сырья выбирают второй способ с целью экономии теплоресурсов и получения биологически доброкачественных субстратов, что позволяет перерабатывать более концентрированные питательные субстраты. Для гидролиза ГЦ лигноцеллюлозного сырья, несмотря на преимущества ФГ ПС перед сернокислотным гидролизом, чаще всего выбирают первый способ, совмещая его с процессом выделения лигнина.

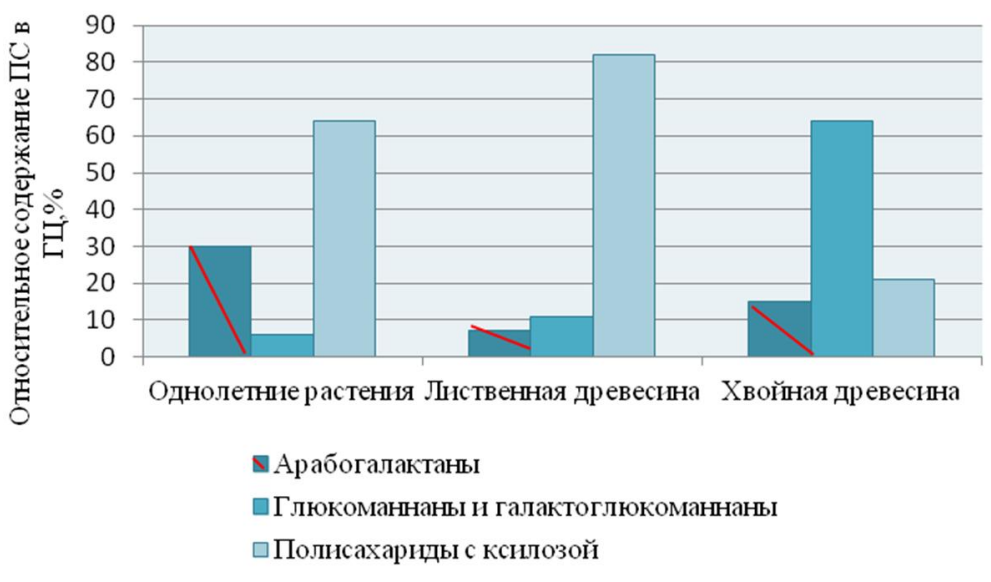

Относительное содержание компонентов в ГЦ растительных тканей 
Лигнин - компонент растительного сырья, неоднородный по своему составу биополимер, имеющий сетчатую структуру. Это продукт сополимиризации следующих трех спиртов: $n$-кумарового, кониферилового, синапового. Содержание, элементный состав, молекулярная масса, количество функциональных групп лигнина, наличие того или иного из трех мономеров-спиртов во всех видах растительного сырья различные. Но, несмотря на такую неоднородность химического состава лигнинов, в различных видах растительного сырья лигнины имеют общие свойства. Все лигнины не растворимы в разбавленных кислотах и растворимы в растворах щелочей и спиртов. Эти свойства лигнина используют при подготовке растительного сырья к ФГ целлюлозы.

Эффективность ФГ полисахаридов (ПС) растительного сырья в основном зависит от следующих факторов: степени измельчения сырья и доступа ФП к поверхности материала; от правильности выбора способа предобработки, параметров его оптимизации; активности и соответствия ферментных препаратов (ФП) данному ПС составу гидролизуемого сырья, оптимальных режимов ФГ [4].

В данном обзоре рассмотрены следующие способы предобработки: гидротермический и щелочной методы для однолетнего сельскохозяйственного сырья; методы делигнификации и методы предобработки без отделения лигнина, такие как бисульфитный (SPORL) и кислотно-каталитический на установке горячего размола (УГР) для пентозан- и целлюлозосодержащего сырья и влияние их на эффективность процессов ФГ ПС сырья и ферментации микроорганизмов в кормовые продукты и этанол.

Оценку эффективности методов предобработки растительного сырья и ФГ ПС проводили по степени конверсии ПС, выходу и качеству целевых продуктов.

\section{Обсуждение литературных данных}

Гидротермическая обработка. Процесс гидротермической обработки (ГО) растительного сырья согласно классификации Токарева и Гельфанда можно отнести к процессам с избытком жидкой фазы, которые могут быть как одноступенчатыми, так и многоступенчатыми. Каждый из них может быть статическим и динамическим, непрерывным и периодическим, прямоточным [2]. В России для крахмалсодержащего сырья чаще используют следующие дешевые периодические виды ГО: гидродинамическая и тепловая обработка замеса (ГДТО) с рециркуляцией суспензии по одному или двум замкнутым контурам, с/без ФП; периодический нагрев в автоклаве с/без ФП (ГО).

Первый процесс предобработки с/без добавок термостабильной $\alpha$-амилазы используют в производствах этанола из зерна и кормовой белковой добавки из зерноотходов. Второй -для получения кормовых добавок и других продуктов биоконверсии в лабораторных условиях и в промышленных автоклавах различной конструкции.

ГДТО заключается в тепловой обработке зерновой пульпы, совмещенной с циркуляцией ее по двум замкнутым контурам. Непрерывность процесса обеспечивают за счет двух аппаратов ГдтО, работающих параллельно. Основными технологическими параметрами процесса ГДТО измельченного зерна являются следующие: фракционный состав измельченного сырья (от 1,0 мм до 2,0 мм), соотношение мука: вода $1: 3,5-5,5 ; \mathrm{t}<100{ }^{\circ} \mathrm{C}$, время 15-20 мин. После ГДТО замес нагревают в контактной головке, температура нагрева зависит от продолжительности ГДТО. ФП задают как в процессе предобработки, так и после. В процессе ГДТО без использования ФП содержание глюкозы в замесе увеличивается в 1,5-2 раза (концентрация глюкозы в замесе составляет $0,47-2,0 \%$ в зависимости от вида сырья), что позволяет снизить расход ФП при осахаривании. ГДТО способствует увеличению доли растворенных сухих веществ сырья в замесе (концентрация а.с.в. в замесе не менее 18\% вес.) и повышению выхода спирта до 88,54-91,64\% от теоретического (концентрация этанола в бражке не менее 9\% вес.) в зависимости от вида сырья [9].

Для получения кормовых добавок чаще используют отходы производств, перерабатывающих крахмалсодержащее сырье (отруби или смесь отрубей и зерноотходов). Исследована ГО пшеничных отрубей в следующих условиях: $Г \mathrm{M}=1: 5-10, \mathrm{t}=60-140{ }^{\circ} \mathrm{C}, \tau=1-34[2,4]$. Установлено, что степень конверсии ПС начинает повышаться только при $\mathrm{t}>80^{\circ} \mathrm{C}$. При ГО с ГМ $1: 10$ в течение 2 ч при $\mathrm{t}=140{ }^{\circ} \mathrm{C}$ степень конверсии редуцирующих веществ после инверсии (РВИ) и степень осахаривания редуцирующих веществ (PB) составила только 88,6 и около $10 \%$ соответственно [2]. Это говорит о том, что для получения питательного субстрата из отрубей для ферментации микроорганизмов необходим ФГ ПС отрубей. Предложены следующие оптимальные условия ГО для последующего ФГ ПС : $Г \mathrm{M}=1: 5-7 ; \mathrm{t}=96-100{ }^{\circ} \mathrm{C}, \tau=1$ ч [2]. Опробованы в лабораторных и опытно-промышленных условиях следующие амилолитические ФП: 
Амилосубтилин, Глюкавамарин (НПО «Восток), Зимаджунт НТ-340 C $\mathrm{N}$, Зимаджунт НТ-340 C $\mathrm{C}^{+}$Амилаза НТ-4000 (Эндэ Индустриал Корпорейшен). Проведены лабораторные исследования комплекса данных амилолитических препаратов с целлюлолитическим ФП Целловиридин (НАО «ВОСТОК»). При ФГ было установлено, что следующий комплекс отечественных ФП: амилосубтилин ГЗх, глюковамарин, целловиридин менее эффективен, чем комплекс ФП Зимаджунт НТ-340 $\mathrm{C}^{+} \mathrm{N}$, содержащий термостабильную $\alpha-$ амилазу, и Целловиридин. Степень конверсии ПС пшеничных отрубей ( $<1$ мм) по редуцирующим веществам после инверсии (РВИ) составила в первом случае $84,7 \%$ и во втором $-92,2 \%$ от их теоретического содержания в сырье (ГМ $1: 7, \mathrm{t}=80-100{ }^{\circ} \mathrm{C}$, время 1 ч). При использовании только одного ФП Зимаджунт HT-340 $\mathrm{C}^{+} \mathrm{N}$, степень конверсии пшеничных отрубей (d<1мм) составляла не более $79,2 \%$; при конверсии не измельченных пшеничных отрубей степень конверсии РВИ не превышала 61-63\%. При ферментации смеси культур Saccharomyces cerevisiae diastaticus ВКПМ-1218, обладающей глюкоамилазной активностью, и Trichosporon cutaneum на таком ферментализате с добавками нейтрализованного сернокислотного гидролизата зерна в количестве 18\% об. в промышленных условиях (состав ферментолизата: а.с.в. 6,7\%, концентрация РВИ $=1,77 \%$, концентрации аммонийного азота 250-600 мг/дм ${ }^{3}$ и $\mathrm{P}_{2} \mathrm{O}_{5} 100-200$ мг/дм ${ }^{3}$ ) содержание сырого протеина и белка по Барнштейну в биосуспензии составило 39,8 и $32,4 \%$ соответственно [2].

Были проведены опытно-промышленные испытания получения кормовой белковой добавки из отрубей и послеспиртовой барды в качестве жидкой водно-минеральной основы. Испытания показали, что измельчение сырья в роторно-пульсационном аппарате в процессе гидротермодинамической обработки (далее ГТДО) с одним циркуляционным контуром способствует повышению эффективности ФГ ПС сырья. Представлена технологическая схема ФГ отрубей. На основе ферментализата была получена кормовая белковая смесь, содержащая дополнительно кормовые дрожжи (соотношение продуктов 45-41:54-59\% соответственно). Продукт имел сырой протеин $(44,0 \%)$ и белок по Барнштейну $(33,6 \%)$ [2].

Экономический анализ опытно-промышленных испытаний показал, что при использовании отрубей в качестве сырья для получения кормовой белковой добавки в структуре ее себестоимости затраты на сырье - всего $15 \%$. Основные затраты приходятся на теплоэнергоресурсы, которые составляют в структуре себестоимости продукта около $40 \%$, в том числе расходы на электроэнергию при эксплуатации оборудования. Основным потребителем электроэнергии являются турбовоздуходувки, используемые для аэрации среды культивирования. Необходима их замена на газодувки типа TN SH 72-1 с расходом электроэнергии в 3 раза меньше [10]. Значительные затраты теплоресурсов происходят при сушке продукта. Содержание а.с.в в дрожжевой пульпе после плазмолиза и перед процессом сушки не должно быть ниже 9-10\%. Или же производство кормовой белковой добавки должно быть приближено к потребителю с целью реализации плазмолизованной дрожжевой пульпы.

По представленным результатам можно сделать вывод, что технологию ГТДО отрубей и ФГ ПС необходимо совершенствовать. Амилолитической активности сахаромицетов недостаточно для осахаривания крахмала. С целью повышения эффективности процесса ферментации и качества кормовой белковой добавки необходимо для осахаривания крахмала вводить фермент глюкоамилазу и для ФГ некрахмалистых ПС сырья - ферменты ксиланазу и целлюлазу.

Для повышения степени конверсии ПС отрубей были исследованы комплексы ФП, содержащие ФП с ксиланазной и целлюлолитической видами активности. При гидротермической обработке отрубей в следующих условиях: гидромодуль - $1: 10$, выдержка при температуре $96-100{ }^{\circ} \mathrm{C}$ в течение 15 мин с последующим ФГ пульпы (pH затора $-4,7-5,0$, температура $-55^{\circ} \mathrm{C}$, время экспозиции -2 ч) комплексом ФП Амилосубтилин ГЗх, Глюковамарин (НПО «Восток», доза внесения 1 г/кг легкогидролизуемых полисахаридов (ЛГПС)), ОРТI-MASH BG, содержищего $\beta$-глюконазу и ксиланазу (10300 CMC U/г) (Genencor, доза 0,05 г/кг), получена степень конверсии ПС 83,9\% от теоретической (состав ферментолизата, \% вес.: а.с.в. 6,$44 ; \mathrm{PB}=2,70 ;$ РВИ = 3,6) $[4,11]$. При использовании следующего комплекса ФП: Амилосубтилин ГЗх, OPTI-MASH BG и GC 220, обладающего целлюлазной, целлобиазной, ксиланазной и $\beta$-глюканазной активностями (6200 IU/г) (Genencor, доза 20 г/кг), Novozymes 188, содержащего целлобиазу (Novozymes, доза 5 г/кг), в тех же условиях была достигнута степень конверсии 96,3\% от теоретической (состав ферментолизата, \% вес.: а.с.в. 10,$00 ; \mathrm{PB}=3,54$; РВИ $=4,94$ ) [4].

Таким образом, для ФГ зерноотходов, предварительно обработанных методом ГТДО, можно рекомендовать ФП GC 220, обладающий целлюлазной, целлобиазной, ксиланазной и $\beta$-глюканазной активностями и OPTI-MASH BG c $\beta$-глюконазной и ксиланазной активностями, в комплексе с амилолитическими ФП. 
Известен способ получения кормовой белковой добавки из зернового сырья (отрубей, зерна, дерти и муки) путем их размалывания с помощью мельницы, принцип действия которой основан на высоком давлении и деформационном сдвиге (ВДиДС), с образованием частиц размером 120-160 мкм и получения водной пульпы с концентрацией а.с.в. 15-25\%. При этом каждый вид зернового сырья, используемого в заявленном способе, может быть использован как по отдельности, так и вместе в любых соотношениях и сочетаниях. Тонкое измельчение ускоряет и повышает эффективность процесса осахаривания. Процесс ГО совмещен с процессом осахаривания, а температура процесса зависит от оптимальных параметров активности ФП. Осахаривание проводили в четыре стадии:

1) стадия разжижения и частичного осахаривания с жидким ФП «Ламинекс БГ2» (Laminex BG2) фирмы Даниско (Дания), представляющего собой комплекс ферментов (глюканазы и сопутствующие им ферменты; ксиланазы и сопутствующие им ферменты), при температуре $50{ }^{\circ} \mathrm{C}, \mathrm{pH}$ 5,0 в течение 30 мин (РВ в пульпе 15,0 г/л);

2) стадия осахаривания с жидким ФП «Амилекс 4Т» (Amylex4T) фирмы Даниско (Дания), представляющего собой термостабильную $\alpha$-амилазу при температуре $86^{\circ} \mathrm{C}, \mathrm{pH} 5,7$, в течение 1 ч (РВ в пульпе 25,6 г/л);

3 ) стадия охлаждения и осахаривания без внесения фермента при температуре $59{ }^{\circ} \mathrm{C}$ и $\mathrm{pH}$ среды 4,8 в течение 1 ч (РВ в пульпе 45,0 г/л);

4) осахаривание с жидким ФП «Диазим ССФ» (Diazym SSF) фирмы Даниско (Дания), представляющего собой комплекс глюкоамилазы и пептидазы, при температуре $59{ }^{\circ} \mathrm{C}, \mathrm{pH} 4,3$ в течение 1 ч (РВ в пульпе 71,0 г/л).

Эффективность авторы оценивают по качеству полученного готового продукта - содержанию сырого протеина. Для получения кормового белкового продукта использовали штамм дрожжей Saccharomyces cerevisiae ВКПМ Y-3585, обладающий амилазной активностью. Содержание сырого протеина в готовом продукте - 49-60\%, а истинного белка - 38\% в зависимости от вида и концентрации зернового сырья в питательной среде [12]. Способ проверен в опытно-промышленных условиях. Основным достоинством метода является экономия теплоресурсов при получении концентрированного питательного субстрата с содержанием а.с.в. $15-25 \%$.

Оценка эффективности совмещенных процессов предподготовки и ФГ по степени конверсии не представлена. Авторами не указаны конкретные цифры по качеству готового продукта при использовании различных видов зернового сырья. Основным недостатком способа является многоступенчатость, так как используемые ФП имеют разные оптимальные условия действия. В процессе осахаривания не использован ФП с целлюлолитической активностью, хотя в отрубях содержание клетчатки составляет около $9 \%$.

С целью повышения качества кормового продукта проводились исследования по использованию в качестве крахмалсодержащего сырья некондиционной муки, отрубей и их смеси в соотношении $1: 1$ с использованием в качестве водной минеральной основы послеспиртовой барды. ГО проводили в следующих условиях: 60-100 ${ }^{\circ} \mathrm{C}$ при рН 4,0-5,5 в течение 1 ч, с содержанием а.с.в. в субстрате от 1 до 8\%. Содержание минерального азота в питательном субстрате было 700-800 мг/дм³. В качестве засевной культуры использовали дрожжи Candida retilis ВСБ-651, обладающие амилолитической активностью. При этом содержание сырого протеина в готовом продукте составило 43,44-44,0\% (барда+5\%отруби); 43,9-46,0\% (барда+5\% смеси отрубей и муки); 46,0-46,8\% (барда+5\% муки). Данный способ получения кормовой белкововитаминной добавки был испытан в опытно-промышленных условиях [13]. В данном способе для приготовления питательного субстрата не использовали процесс ФГ ПС.

При сравнении эффективностей данного метода подготовки питательного субстрата из смеси отрубей и муки без ФГ (сырой протеин 43,9-46,0\%) и методом с тонким измельчением сырья с последующим ФГ ПС (сырой протеин 49-60\%) преимущества на стороне метода с ФГ ПС. Амилолитической способности штаммов дрожжей - продуцентов белка, используемых в данных примерах, недостаточно для их эффективной ферментации на суспензионном крахмалсодержащем субстрате.

Из представленных данных можно сделать выводы, что для получения продукта с более высоким показателем по сырому протеину: во-первых, в питательный субстрат из отрубей необходимо добавлять крахмалсодержащее сырье с более высоким содержанием углеводов, например некондиционную муку и другие зерноотходы; во-вторых, обязательное проведение ФГ всего комплекса ПС крахмалсодержащего сырья.

Можно рекомендовать следующую технологию получения питательного субстрата в производстве кормовой белковой добавки из смеси отрубей и других зерноотходов с более высоким содержанием крахмала: 
- включение в схему дополнительного процесса тонкого измельчения зерносырья;

- для предподготовки зерносырья к ФГ необходимо использовать метод ГТДО с обогревом паром при следующем технологическом режиме: а.с.в. $15 \%, \mathrm{t}=86-100{ }^{\circ} \mathrm{C}$, время выдержки при этой температуре не более 1 ч с ФП (Зимаджунт 340С* или Амилаза НТ-4000 (ЭНДЭ ИНДУСТРИАЛ КОРПОРЕЙШЕН, США) или Амилекс 4Т (Даниско, Дания)), содержащим термостабильную $\alpha$-амилазу, температура зависит от оптимальных условий действия ФП;

- охлаждение до $\mathrm{t}=55^{\circ} \mathrm{C}$; -

- ФГ важно осуществлять в оптимальных условиях (рН затора 4,7-5,0, температура $55{ }^{\circ} \mathrm{C}$, продолжительность процесса 2 ч) следующим комплексом ФП: Глюковамарин (НПО «Восток), GC 220, обладающий целлюлазной, целлобиазной, ксиланазной и $\beta$-глюканазной активностями (Genencor International), Novozymes 188, содержащий целлобиазу (AO Novozymes, Дания).

Дальнейшее совершенствование технологии должно состоять в селекции используемых микроорганизмов с целью получения штаммов, способных перерабатывать более концентрированные субстраты.

Метод ГО используют и для подготовки к ФГ отходов растениеводства - лигноцеллюлозного растительного сырья.

Эффективность гидротермической предобработки (фракция с $\mathrm{d}<1$ мм, гидромодуль $1: 7$, выдержка при температуре $120{ }^{\circ} \mathrm{C}$ в автоклаве в течение 60 мин) к ФГ была исследована для однолетнего пентазансодержащего сырья - биомассы кукурузной кочерыжки (КК). ФГ состоял из двух следующих стадий: с использованием комплекса ФП: Ксиланаза (ОАО «Восток», доза 5 г/кг), и ОРТI-MASH ВG (доза 0,3 г/кг), (условия ФГ: $\mathrm{pH} 5,5-4,5$; температура $50 \pm 2{ }^{\circ} \mathrm{C}$; время 1 ч); после корректировки рН с дополнительным введением ФП GC-220 (доза 20 г/кг) и МЭК СХ-3 (ОАО «Восток», доза 10 г/кг, обладает целлюлазной

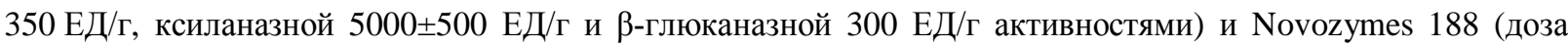
5 г/кг) (время 24 ч) $[4,8]$.

При таком режиме обработки биомассы КК максимальная степень биоконверсии ПС от содержания их в абсолютно сухом сырье (а.с.с.) составила $70 \%$ (состав гидролизата, г/л: РВ = 43,8; РВИ = 63,6; состав моносахаридов без инверсии: глюкоза - 30,0; фруктоза - 6,7; ксилоза - 2,3; арабиноза - 0,8) $[4,8]$. При достаточно эффективном способе конверсии пентозан и гексозан биомассы КК концентрации ксилозы и глюкозы в гидролизате должны быть на одном уровне, чего не было достигнуто. Недостаточно высокую степень конверсии ГЦ биомассы КК можно объяснить малоэффективным способом предобработки для пентозансодержащего сырья. Для оптимизации процессов требуется проведение дополнительных работ.

ГО соломы зерновых проводили в широком интервале температур от $100{ }^{\circ} \mathrm{C}$ до $230{ }^{\circ} \mathrm{C}$ в течение от 5 мин до 2,5 ч. При $\mathrm{t}>230^{\circ} \mathrm{C}$ начинается гидролиз целлюлозы [14-16]. Установлено, что уже при температуре $121^{\circ} \mathrm{C}$, давлении 2,0 атм и экспозиции 0,25 ч в растительном сырье наблюдаются разрыв и нарушение пространственной ориентации волокон целлюлозы, снижается ее кристалличность, что делает сырье более доступным для последующего биокатализа и воздействия микроорганизмов. При этом осахаривание соломы происходит в основном до олигосахаров, образование моносахаридов минимальное. Кроме углеводов жидкая фракция содержит продукты распада моносахаридов. Такой продукт в России в основном используют в качестве кормового продукта [15].

При ГО рисовой соломы ( $\mathrm{t}=180$ и $200{ }^{\circ} \mathrm{C}$ в течение 30 и 10 мин соответственно) гидролиз глюкана и ксилана незначительный, но данные режимы обеспечивают удовлетворительную степень ФГ глюкана $(85 \%)[16]$.

При ГО (t = 200-230 C) кукурузного волокна ГЦ гидролизуются полностью, целлюлоза - незначительно, около половины лигнина растворяется. В результате ФГ обработанного волокна степень конверсии целлюлозы составила от 33 до 84\% к глюкозе и необработанного волокна 17\% [17].

ГО пентозан- и целлюлосодержащего сырья имеет ряд особенностей. Обработку проводят при температурах более высоких от 180 до $230{ }^{\circ} \mathrm{C}$ при давлении 2,0 МПа в течение 0,5-15 мин в зависимости от вида сырья. При этом идут реакции деструкции гемицеллюлоз, например дезацетилирования с образованием уксусной кислоты, которая катализирует процесс гидролиза ГЦ. При $\mathrm{t}>230{ }^{\circ} \mathrm{C}$ начинается гидролиз целлюлозы $[2,14,17,18]$. Метод называют автогидролизом, отнести его к чисто гидротермическим по этой причине нельзя. Общепризнано, что по эффективности он уступает другим кислотно-каталитическим методам гидролиза. Максимальная степень конверсии целлюлозы древесной щепы и отходов переработки однолетних растений в глюкозу после автогидролиза с паровым взрывом и ФГ достигает 68-85\% [2]. Ме- 
тод рекомендуют только для конверсии однолетних растений с последующим ФГ целлюлозы и получения кормовых продуктов.

Таким образом, по ГО методам предподготовки растительного сырья к ФГ можно сделать следующие выводы:

- разновидность метода ГО - гидродинамическую (оптимальный режим: выдержка при $\mathrm{t}<100{ }^{\circ} \mathrm{C}$ в течение 15-20 мин) и тепловую обработки с рециркуляцией по двум контурам (ГДТО) применяют для получения биоэтанола из крахмалсодержащего сырья, технология метода апробирована в процессе длительного промышленного производства;

- при получении кормовой белковой добавки из смеси отрубей и зерноотходов оптимальным режимом предподготовки является следующий: тонкое измельчение сырья и ГТДО при $\mathrm{t}=86-100{ }^{\circ} \mathrm{C}$ в течение 1 ч с ФП, содержащим термостабильную $\alpha$-амилазу;

- при получении кормовых добавок из пентозан- и целлюлозосодержащего однолетнего сырья используют следующий режим предподготовки: ГО при $\mathrm{t}=180-230{ }^{\circ} \mathrm{C}$ в течение $0,25-15$ мин, а также данный режим можно рекомендовать без последующего ФГ для подготовки однолетних растений к таким процессам биоконверсии, как компостирование и метановое брожение.

Одним из первоначальных процессов предподготовки биомассы растительного сырья к ФГ является его размол.

Особенности размола растительной биомассы. С тем, чтобы обеспечить доступ ферментов к ПС растительных материалов, повысить поверхность гидролизуемого материала, снизить кристалличность целлюлозы и плотность упаковки фибрилл в клеточной оболочке их измельчают [2, 8, 9, 18-27]. Для измельчения используют следующие виды оборудования: рубительные машины для древесного сырья на первой стадии для получения технологической щепы и молотковые и вальцовые дробилки, дисковые, ножевые, дисковые, молотковые и шаровые мельницы, мельницы высокого давления и деформационного сдвига и другие для всех видов растительного сырья для тонкого измельчения.

Измельчение сырья проводят как в «сухом», так и в «мокром» виде.

Ряд авторов отмечают, что «сухой» размол лигноцеллюлозного сырья увеличивает его реакционную способность. Метод «сухого» измельчения используют как для лигноцеллюлозного, так и для крахмалсодержащего сырья для повышения эффективности процессов предобработки и биоконверсии [20, 21].

Проведены исследования по влиянию «сухого» и «мокрого» размола в водной среде, концентрации суспензии (1-10\%) на степень измельчения и деструкции опилок древесины хвойных пород. Размол опилок производился на экспериментальных установках кафедры МАПТ СибГТУ: дисковая мельница; центробежный размольный аппарат с инерционным движением рабочих тел; безножевая размалывающая установка типа «струя - преграда». При «сухом» размоле древесины, даже при низком градусе помола, происходят изменения в ее химическом составе. В результате «сухого» размола происходит частичная деструкция целлюлозного волокна, содержание целлюлозы в древесине после размола по сравнению с исходным образцом меньше на 9,87\%. Аналогичный распад ПС наблюдается и при гидроразмоле. Это снизит выход сахара при ФГ и выход биоэтанола. Авторы отдали предпочтение гидроразмолу суспензии с оптимальной концентрацией сырья 6\% по причинам самого высокого градуса помола и высокой концентрации РВ (11\%) в водной среде. Сделан вывод, что обработка сырья в измельчительных аппаратах различного типа приводит к изменению в химическом составе его полисахаридного комплекса. Наибольшие изменения в биомассе происходят в аппаратах типа «струя - преграда» при концентрации сырья в суспензии $1 \%$ [22].

В большинстве опубликованных работ по измельчению обсуждаются только энергетические затраты и размер частиц, не приведены данные влияния степени измельчения на эффективность ФГ целлюлозы.

На энергетические затраты в процессе тонкого измельчения влияют следующие три фактора: степень измельчения, тип механизмов тонкого измельчения и метод предобработки (термохимический или механохимический или биологический), предшествующий измельчению или проводимый после или одновременно с измельчением [22-27].

Установлено, что при использовании фрезерного ножа с увеличением степени «сухого» измельчения стружки ( $\mathrm{d}=5-12,5$ мм) биомассы тополя в интервале размера частиц от 4 до 1 мм энергетические затраты возрастают в 5 раз. Проведены исследования влияния влажности сырья на энергетические затраты при «сухом» измельчении. При увеличении влажности с 7-10 до 18\% потребление энергии значительно увеличивается. Та же тенденция была найдена при измельчении пшеничной, ячменной и кукурузной соломы, 
проса прутьевидного с помощью молотковой дробилки. Увеличение влагосодержания (7-18\%) целлюлозной биомассы приводит к увеличению сдвиговой прочности биомассы; следовательно, больше энергии расходуется на измельчение целлюлозной биомассы [23].

Все приведенные выше исследования и выводы справедливы для «сухого» и «мокрого» измельчения без присутствия химических реагентов. Но интенсивные методы предобработки проводят в присутствии кислот и других реагентов и совмещают их с процессом тонкого измельчения биомассы.

В случае горячего («мокрого») размола древесной щепы присутствие кислотного катализатора в большей степени влияет на геометрию частиц, чем параметры измельчаемой технологической щепы. Даны зависимости снижения расхода электроэнергии от повышения расхода кислоты (0-14\% от а.с.с.) и температуры $\left(\mathrm{t}=135-180^{\circ} \mathrm{C}\right)$. Минимальный расход электроэнергии составляет около 100 кВт ч/т а.с.с. при расходе кислоты $12-14 \%$ от а.с.с и $\mathrm{t}=165-180{ }^{\circ} \mathrm{C}[24]$.

Приведены зависимости энергетических затрат при «мокром» измельчении древесиной щепы от размера частиц после измельчения (0,4-4,0 мм) и способов предобработки (гидротермический рН 5,0; разбавленной кислотой рH 1,1; бисульфитный SPORL pH 4,2 и 1,9). Минимальные энергетические затраты (810 КВт ч/т исходной древесины) наблюдаются в случае рН 1,1 и 1,9 и полученном размере частиц 2,5-4,0 мм и максимальные (56-80 КВт ч/т исходной древесины) при полученном размере частиц 0,4 мм [25].

Указанные выше факторы, влияющие на энергетические затраты при измельчении растительного сырья, также воздействуют на эффективность процессов осахаривания при ФГ целлюлозы и микробиологического синтеза растворителей $[3,23,26]$. Только отдельные исследователи отвечают на этот вопрос и не однозначно. Для оценки влияния размера частиц на выход глюкозы при ФГ целлюлозы гидролиз проводили в две ступени:

- предобработка методом сернокислотного гидролиза в водном 2\% растворе серной кислоты (ГМ $20: 1, \mathrm{t}=140^{\circ} \mathrm{C}$ в течение 30 мин) с последующей промывкой лигноцеллюлозного остатка горячей дистиллированной водой в течение 15 мин три раза;

- ФГ с ФП Accellerase 1500 (Danisco US Inc., Rochester, NY, USA), содержащим следующий комплекс ферментов: экзоглюконаза, эндоглюконаза, гемицеллюлазы и $\beta$-глюкозидазы (концентрация а.с.в. $5 \%$, концентрация фермента 1 мг/г а.с.в., $\mathrm{t}=50{ }^{\circ} \mathrm{C}$ в течение 72 ч).

При измельчении древесной щепы с влажностью 1,2\% до размера частиц 4 мм выход сахара в процессе гидролиза (около11 мг/мл) выше, чем до 2 и 1 мм (8 мг/мл) [23]. Другими авторами для пшеничной и кукурузной соломы при измельчении молотковой дробилкой до размеров частиц 3,2 и 6,5 мм получены аналогичные закономерности [23]. При измельчении красных дубовых опилок и еловой щепы с использованием молотковой дробилки получены противоположные результаты. Но размеры частиц были намного меньше, при $\mathrm{d}=0,03-0,08$ мм - концентрация сахаров 18 мг/мл и при $\mathrm{d}=0,59-0,85$ мм - 10 мг/мл [23].

Проведены исследования влияния разных измельчающих механизмов на эффективность ФГ еловой щепы. Для этой цели были взяты две дисковых мельницы разной конструкции и одна молотковая. Установлено, что конструкции измельчающих механизмов оказывают существенное влияние на эффективность ФГ целлюлозы [26].

Исследовано влияние механической обработки в процессе ФГ целлюлозы древесных опилок, соломы пщеницы, кукурузы и лигноцеллюлозы пальмы. Получены положительные результаты [27].

Под действием химической или ферментативной обработки биомассы сырья изменяются ее химический состав, физическая структура, гидролизуются, деструктируют и растворяются в водных растворах ГЦ, лигнин, продукты деструкции. Как результат, проведение химической обработки до или в процессе размола и ФГ в процессе размола снижают энергетические затраты при измельчении. Это снижение энергетических затрат может быть незначительным для некоторых сельскохозяйственных культур, таких как солома зерна или трава, но существенна для более структурированной биомассы (древесина, бамбук и тростник) [3, 24-27].

Следовательно, в каждом отдельном случае в зависимости от вида растительного сырья, технологии предобработки и механизмов измельчения необходимо оптимизировать процесс тонкого измельчения и проводить его после или одновременно с термохимической обработкой или одновременно с ферментативной предобработкой.

ФГ биомассы как многолетних, так и однолетних растений проводят как с использованием способов делигнификации, так и без выделения лигнина. Для этого необходимо знать эффективность различных методов предобработки, а также концентрацию остаточного лигнина в лигноцеллюлозном остатке, позволя- 
ющие эффективно проводить процессы ФГ целлюлозы и ферментации продуцентов биорастворителей (этанола, бутанола).

Делигнификация пентозан- и целлюлозосодержащего растительного сырья. В данной работе рассмотрены следующие известные методы предподготовки древесного сырья с отделением лигнина и ГЦ от целлюлозы: органосольвентные с получением технической целлюлозы; органосольвентный с серной кислотой; кислотно-катализируемый с паровым взрывом; щелочные и их комбинации.

Органосольвентные методы с получением технической целлюлозы. Проводятся многочисленные исследования по интенсификации процесса делигнификации древесины лиственных и хвойных пород с получением технической целлюлозы для целлюлозно-бумажной промышленности. С этой целью был сделан анализ следующих методов делигнификации: крафт, сульфитный, натронный, окислительно-щелочные, органосольвентные [3]. Сделан вывод, что при использовании лиственной древесины наиболее эффективными являются органосольвентные технологии $\mathrm{SEW}$ (концентрации $\mathrm{SO}_{2} 15 \%$, этанола $50 \% ; \mathrm{t}=135{ }^{\circ} \mathrm{C}$, $\tau=40$ мин, гидромодуль 6, выход целлюлозы 54,3\%, остаточный лигнин 3,1\%) [28] и кислородно-щелочная с 1,10-фенонтролином в количестве $0,5 \%\left(\mathrm{t}=160{ }^{\circ} \mathrm{C}, \tau=115\right.$ мин, гидромодуль 10 , выход 58,5\%; число Каппа 10,9) [29]. При получении технической целлюлозы из хвойной древесины наиболее эффективными являются следующие органосольвентные технологии: - Acetcell (этанол - вода - уксусная кислота $35: 35: 30$; $\mathrm{t}=185^{\circ} \mathrm{C}, \mathrm{P}=1,85-1,96$ МПа. $\tau=160-185$ мин, гидромодуль 4, выход 45-49\%) [30]; - SEW (концентрации $\mathrm{SO}_{2} 12 \%$, этанола $50 \% ; \mathrm{t}=170{ }^{\circ} \mathrm{C}, \tau=70$ мин, гидромодуль 6-7, выход 51,2\%, число Каппа 30, остаточный лигнин 3,1\%) [28]; Organosell c антрохиноном ( $\mathrm{NaOH} 17-22 \%$, метанола 25-40\% об; $\mathrm{t}=155-170{ }^{\circ} \mathrm{C}, \tau=60$ 120 мин, гидромодуль 4,2; выход 56-58\%, число Каппа 20-30) [31, 32]; натронная с антрохиноном и изобутанолом (пропитка $\mathrm{NaOH} 70-90$ г/л $\mathrm{Na}_{2} \mathrm{O}$, изобутанол; $\mathrm{t}=156^{\circ} \mathrm{C}, \tau=180$ мин, гидромодуль 4, выход 48,6\%, число каппа 25-30) [33]; ASAM ( $\mathrm{Na}_{2} \mathrm{O}$ 19,4\%, антрохинон 0,1\%, $\mathrm{Na}_{2} \mathrm{SO}_{4} / \mathrm{NaOH} 80 / 20$, метанол 20\% об.; $\mathrm{t}=180{ }^{\circ} \mathrm{C}, \tau=110+160$ мин, гидромодуль 3-5, число Каппа 22,1) [34, 35].

При переработке как лиственной, так и хвойной древесины преимущества на стороне метода SEW. Ниже затраты на теплоэнергоресурсы, проще технологии регенерации химикатов, есть возможность организации замкнутого цикла водопользования.

Основным недостатком SEW-способа является более низкое качество целлюлозы по параметру «сопротивление разрыву» в сравнении с крафт-целлюлозой. Опытно-промышленные испытания показали перспективность использования технологии получения целлюлозы из древесины хвойных пород методами Organosell и ASAM. Но данные способы промышленного внедрения не получили, так как требуются значительные капитальные затраты на осуществление дополнительной стадии регенерации растворителя и реагентов [3, 36, 37]. В настоящее время широко рекламируют технологию «formicobio» (компания Chempolis, Финляндия) с использованием катализатора $\mathrm{SO}_{2}$ и с циркуляцией биорастворителя в процессе гидролиза как древесной, так и не древесной растительной биомассы с получением бумаги или биорастворителей и других продуктов гидролизной промышленности.

Основные достоинства органосольвентных способов для производства целлюлозы заключаются в том, что они позволяют сократить сброс сточных вод на очистные сооружения за счет снижения гидромодуля (ГМ) по воде и экономить теплоэнергоресурсы в процессе варки и при концентрировании отработанного варочного раствора. Но пока отсутствуют органосольвентные способы получения целлюлозы, более эффективные с экономической точки зрения, чем сульфатный. Несмотря на это, рассмотренные способы делигнификации древесины и получения целлюлозы могут быть использованы в производстве жидкого биотоплива и ксилита из концентрированного раствора ГЦ после выделения растворителя.

Органосольвентный метод с серной кислотой. Органосольвентный метод предподготовки лигноцеллюлозного сырья заключается в фракционировании компонентов сырья и делигнификации целлюлозы. При термохимической обработке сырья в присутствии водного раствора органического растворителя и кислоты с последующей промывкой в две ступени целлюлозной массы водным раствором органического растворителя и затем водой позволяет выделить в раствор продукты гидролиза ГЦ и лигнин. Целлюлоза остается в остатке. Предлагаемая технологическая схема с использованием данного метода предобработки состоит из следующих технологических стадий [37]:

1) предобработка: сырье, 40-80 об.\% водный раствор органического растворителя, чаще этанола или метанола, или их смеси; кислотный катализатор (этанол 55-75\%, серная кислота концентрацией 0,9-1,44\%; ГМ $1: 7-13,5)$ задают в аппарат, где осуществляют прогрев до $\mathrm{t}=170-198^{\circ} \mathrm{C}$ и выдержку в течение $15-77$ мин;

2) противоточная экстракция пульпы - промывка $70 \%$ водным раствором этанола;

3) испарение раствора с выделением паров этанола; 
$4,5)$ охлаждение и отделение лигнина путем фильтрования смеси гидролизата и промывочного раствора;

6) дистилляция с выделением спирта из ГЦ гидролизата и получением фурфурола;

7) вакуум упаривание ГЦ гидролизата с получением экстрактивных веществ и уксусной кислоты;

8) декантация упаренной пульпы с получением осветленного концентрированного раствора ГЦ с концентрацией $35 \%$ а.с.в. и низкомолекулярного лигнина;

9) промывка водой целлюлозосодержащего остатка с содержанием лигнина до 18\%;

10) ФГ целлюлозного остатка (2-15\% концентрация остатка, ферментные препаратаы с целлюлазной и $\beta$-глюкозидазной активностями в соотношении их $2: 1$ и количестве целлюлазы от 5 до 40 FPU/Г целлюлозы; время от 24 ч до 72 ч, $\mathrm{t}=45-50{ }^{\circ} \mathrm{C}, \mathrm{pH} 4,8 ; \mathrm{n}=150$ об/мин);

11) ферментация культур микроорганизмов на смеси ферментативного гидролизата и осветленного ГЦ гидролизата.

Установлено [37], что эффективность ФГ технической целлюлозы (ФП Celluclast и Novozim 188), полученной путем органосольвентной делигнификации смеси хвойных видов древесины (сосна, ель, пихта), имеет обратную зависимость от остаточного содержания лигнина в целлюлозном остатке. Варку проводили в следующих условиях: варочный водный раствор этанола $1: 1$ с серной кислотой как катализатором при рН 2,0-3,4; t = 185-198 ${ }^{\circ} \mathrm{C}$, продолжительность 30-60 мин, ГМ 7-10 : 1; с последующей промывкой $70 \%$ этанолом. ФГ были подвергнуты 3 образца целлюлозного остатка с содержанием остаточного лигнина 6,4, 18,4 и 9,2\%. Процесс проводили в следующих условиях: концентрация целлюлозы в суспензии $2 \%$, расход целлюлазы 20 FPU/г целлюлозы. При этом было установлено, что выход глюкозы от целлюлозы составляет более 90\% при продолжительности ФГ первого образца целлюлозы 24 и 48 ч для других образцов. При расходе целлюлазы 40 FPU/г целлюлозы выход глюкозы от целлюлозы составил 90 $100 \%$ для всех образцов. Установлено, что чем ниже содержание лигнина в целлюлозе, тем меньше время процесса. Время гидролиза для образцов с содержанием лигнина 6,4; 9,2; 18,4 и 28,4\% составило 12,36 и 48 ч для двух последних образцов соответственно. При повышении концентрации суспензии до $10 \%$ в процессе ФГ степень конверсии целлюлозы снижается, выход глюкозы составляет 72\% как с расходом целлюлазы 20, так и 40 FPU/г целлюлозы за время 48 ч. Процессы ФГ делигнифицированной целлюлозной массы и ферментации культуры Saccharomyces cerevisiae проводили раздельно и совместно. В случае раздельного проведения процессов степень конверсии целлюлозы в глюкозу при ФГ целлюлозной массы (расход целлюлазы $40 \mathrm{FPU} / г$ целлюлозы, $\tau=8$ ч) составила $90 \%$ от теоретической и степень конверсии глюкозы в этанол при времени брожения 8 ч - 90\% от теоретической (теоретический выход 0,51 г этанола /Г глюкозы). В случае совместного проведения процессов степень конверсии целлюлозы в этанол при времени брожения 24 ч составила 84\% от теоретической (теоретический выход 0,57 г этанола/г целлюлозы) [3, 37]. В пересчете на глюкозу выход этанола составит около $76 \%$ от теоретического.

Следовательно, преимущества на стороне раздельного ведения процессов ФГ и ферментации как по продолжительности процессов, так и по степени конверсии глюкозы в этанол (раздельное 20 ч и $90 \%$, совместное 24 ч и $76 \%$ соответственно) [3].

Таким образом, при оптимальном технологическом режиме паровой органосольвентной предобработки с серной кислотой (концентрация $\mathrm{H}_{2} \mathrm{SO}_{4}$ 0,9-1,1\%; этанола 55-75\%, $\mathrm{t}=170-180{ }^{\circ} \mathrm{C}$, время выдержки 50-77 мин и ГМ $7: 1$ ) выход твердого остатка составляет 37,7-40,8\% с содержанием лигнина Классона 9$11 \%$; степень выделения лигнина изменяется от 66 до 75\%. При данном режиме после предподготовки и ФГ получен высокий выход сахаров - более $90 \%$. При ФГ целлюлозной массы с концентрацией $2 \%$ с ферментами целлюлазой (Celluclast) и $\beta$-глюкозидазой (Novozim 188) (в соотношении $1: 2$, доза целлюлазы 10-20 FPU/г целлюлозы) в зависимости от вида сырья степень конверсии целлюлозы в глюкозу составила от 80 до 98\% за разное время - от 24 до 72 ч; при концентрации целлюлозной массы $10 \%$ и концентрации фермента 20-40 FPU/г целлюлозы степень конверсии целлюлозы в глюкозу была более $70 \%$ за время от 36 до 48 ч. В процессе ферментации культуры Saccharomyces cerevisiae достигнут высокий выход этанола 0,46 г/г сахаров или $90 \%$ от теоретического и более. Данные по преимуществу раздельного и совместного проведения процессов ФГ и ферментации противоречивые.

Основные достоинства органосольвентного кислотного способа предобработки заключаются в том, что можно получить концентрированный раствор ГЦ с меньшим расходом теплоэнергоресурсов и питательный субстрат для ферментации микроорганизмов более высокой биологической доброкачественности, чем при перколяционном гидролизе.

В процессе ФГ лигноцеллюлозного остатка с содержанием лигнина 18,4\% за 48 ч с концентрацией фермента 20FPU/г целлюлозы выход глюкозы от целлюлозы составляет не менее 90\%. 
Предлагаемая технологическая схема на основе органосольвентного кислотного способа предобработки имеет следующие основные недостатки: в процессах испарения и охлаждения будет выделяться коллоидный лигнин и забивать оборудование и трубопроводы; многоступенчатость; дополнительные затраты на регенерацию растворителя.

Данный метод может быть использован при получении биобутанола. В процессе экстрактивной ацетоно-бутиловой ферментации клостридий есть возможность делать доливки концентрированным ГЦ, нейтрализованным гидролизатом.

Кислотно-катализируемый метод с паровым взрывом [2, 3, 38-50]. Для данного метода в качестве гидролизеров используют экструдеры непрерывного действия. Метод предподготовки к ФГ относится к непрерывным динамическим процессам по жидкой и твердой фазам. Процесс может быть одноступенчатым и многоступенчатым, прямоточным и противоточным [2].

В экструдерах растительное сырье подвергают механохимическому деформированию и термическому воздействию. Механическое воздействие на биомассу обусловлено высоким давлением (до 5002000 МПа) в сочетании с деформацией сдвига (до 800), а также паровым взрывом при перепаде давлений на выходе частично гидролизованной биомассы из фильер. Высокое давление создается за счет пробок на входе и выходе экструдера, создаваемых обрабатываемым сырьем, а также паром. Для усиления процесса гидролиза при экструдировании используют водные растворы кислот или газ $\mathrm{SO}_{2}$. Быстрый разогрев биомассы (от 10 с до 10 мин) осуществляется за счет комплексного воздействия сил трения, давления, а также различными средствами внешнего обогрева. При этом происходит деструкция биомассы. Разрушаются лигноуглеводные связи, увеличивается реакционная поверхность ПС. Под действием кислоты и нагрева происходит разрыв $1 \rightarrow 4-\beta$-глюкозидных связей, ГЦ гидролизуются до олигосахаров и моносахаридов и переходят в раствор, снижается степень полимеризации целлюлозы, в биомассе увеличивается содержание легкогидролизуемой фракции до 10-25\% и реакционная способность целлюлозы к ФГ. Идет процесс деацелирования с образованием уксусной кислоты. Глубина деструкции биомассы зависит от величины давления и количества кислоты [38].

Технологическая схема получения биоэтанола и побочных продуктов, включающая кислотнокатализируемый $\mathrm{SO}_{2}$ с паровым взрывом метод предподготовки лигноцеллюлозного сырья с последующей промывкой остатка, состоит из следующих технологических стадий [38-50]:

1) древесный опил, пар и $\mathrm{SO}_{2}$ подают в экструдер, где проходит ряд операций: быстрый разогрев биомассы за счет механохимического деформирования и нагрева паром, гидролиз гемицеллюлоз при оптимальных режимах; отделение раствора гемицеллюлозных сахаров; паровой взрыв и дополнительное деформирование целлюлозосодержащего остатка при выдаче ее через фильеры экструдера за счет разности давления в экструдере и атмосфере;

2) промывка водой или водой и $1 \%$ щелочным водным раствором пероксида водорода целлюлозосодержащего остатка биомассы древесины в зависимости от содержания лигнина в древесном сырье;

3) отделение промывных вод от целлюлозосодержащего остатка путем центрифугирования и смешение с гидролизатом моно- и олигогемицеллюлоз;

4) испарение и инверсия гидролизата гемицеллюлоз с целью выделения легколетучих продуктов распада сахаров и деструкции лигнина и гидролиза олигосахаров до моносахаров;

5) ФГ целлюлозосодержащего остатка;

6) корректировка $\mathrm{pH}$ суспензии смешанных гидролизатов;

7) декантация смеси нейтрализованных гидролизатов, выделение лигнина и использование его в качестве топлива;

8) ферментация культуры дрожжей Sacharomyces cerevisiae на смеси осветленных нейтрализованных гидролизатов;

9) многоступенчатая очистка послеспиртовой барды с получением кормовых дрожжей и органоминерального удобрения [2].

Процесс кислотно-катализированный с паровым взрывом был исследован и оптимизирован многими авторами. При переработке биомассы лиственных пород древесины проведены исследования в широком интервале изменения температур от 190 до $226^{\circ} \mathrm{C}$ и концентраций $\mathrm{SO}_{2}$ 1,6-3,0\% и $\mathrm{H}_{2} \mathrm{SO}_{4}$ 0,25-0,6\%. Оптимальными параметрами технологических режимов с использованием серной кислоты для лиственных пород древесины являются следующие: концентрация $\mathrm{H}_{2} \mathrm{SO}_{4}-0,58 \%, \tau=1,33$ мин, $\mathrm{t}=200{ }^{\circ} \mathrm{C}$, с промывкой водой, выход ГЦ $-84,7 \%$ от теоретического [3, 39]. 
При переработке биомассы хвойных видов сырья оптимизация проведена в интервалах температур от 182 до $290{ }^{\circ} \mathrm{C}$ и концентраций кислот от 0,5 до 4,5\% в течение 0,55-20 мин [41]. Оптимальными параметрами технологических режимов с использованием серной кислоты являются следующие: концентрация $\mathrm{H}_{2} \mathrm{SO}_{4}-0,5-0,65 \%, \tau=1,67$ мин, $\mathrm{t}=215{ }^{\circ} \mathrm{C}$, выход ГЦ $-79 \%$ от теоретического $[3,42,43,47]$. Основные данные литературных источников при использовании в качестве катализатора $\mathrm{SO}_{2}$ представлены в таблице.

По данным таблицы видно, что для хвойных видов древесины оптимальными являются следующие условия гидролиза: концентрация $\mathrm{SO}_{2}-4,0-4,5 \%, \mathrm{t}=195-200{ }^{\circ} \mathrm{C}$, время 4,0-4,5 мин, промывка водой, обеспечивающие выход ГЦ не менее $96 \%$ от теоретического их содержания в а.с.с. [45, 48].

Максимальные результаты по выходу сахаров (>100\% от ГЦ) и этанола (90\%) получены в случае предподготовки образцов биомассы заболони и ядра ели Douglas-fir путем парового взрыва с $\mathrm{SO}_{2}$ (концентрация $\mathrm{SO}_{2} 4,5 \%, \mathrm{t}=195^{\circ} \mathrm{C}$, время 4,5 мин) с промывкой целюлозосодержащего остатка (остаточное содержание лигнина $8 \%$ ) водой и раствором пероксида водорода (pH 11,$5 ; 1 \% \mathrm{H}_{2} \mathrm{O}_{2} ; \mathrm{t}=85{ }^{\circ} \mathrm{C}$, время 45 мин). Представлены данные по содержанию лигнина в целлюлозосодержащем остатке при указанных выше условиях предобработки с разными режимами промывки, влияющими на остаточное содержание лигнина в нем. При водной промывке при $\mathrm{t}=25^{\circ} \mathrm{C}$ содержание лигнина в экструдированной биомассе составляет $46 \%$. При промывке водным $0,4 \%$ раствором $\mathrm{NaOH}$ с содержанием $1 \% \mathrm{H}_{2} \mathrm{O}_{2}(\mathrm{pH} 11,5)$ при $\mathrm{t}=25^{\circ} \mathrm{C}$ в течение 12 ч содержание лигнина в экструдированной биомассе составляет $16 \%$. При использовании этого же раствора при $\mathrm{t}=80^{\circ} \mathrm{C}$ в течение 0,75 ч $-8 \%$. Согласно данным материального баланса технологической схемы с промывкой целлюлозосодержащего остатка только водой в одну ступень [43], видно, что часть целлюлозы гидролизована. Результаты показали, что в промывную воду перешло около $72 \%$ ГЦ сахаров и около $21 \%$ гексозных сахаров от содержания целлюлозы в сырье. В целом в промывных водах содержится около $38 \%$ сахаров от ПС сырья (из них ГЦ 22\%) и в остатке деструктированной целлюлозы около $44 \%$ от ПС в сырье, что в сумме составляет около $82 \%$ от ПС в сырье. При последующей промывке окислительнощелочной водой в раствор перешло дополнительно $21 \%$ сахаров от ГЦ (около 6\% сахаров от суммы ПС в исходном сырье) из них 40\% пентозы. Всего получено пентоз 81\% от ГЦ в сырье. Часть пентоз в процессе кислотно-каталитического парового взрыва распалась: идет реакция их дегидратации с образованием фурфурола, муравьиной кислоты и гуминовых веществ. С промывной водой выделилось $3 \%$ от содержания лигнина в исходной древесине. С щелочной водой, содержащей пероксид водорода, выделилось $65 \%$ лигнина. В остатке после ФГ содержалось $27 \%$ лигнина от его количества в исходном сырье. Общая сумма составляла $92 \%$ от исходного лигнина в сырье, $8 \%$ - потери.

Таким образом, по данному примеру видно, что с водой $\left(\mathrm{t}=25^{\circ} \mathrm{C}\right)$ выделилось сахаров более $>100 \%$ от ГЦ (38\% от ПС сырья) и около 3\% лигнина от содержания их в сырье. С окислительно-щелочными промывными водами сахаров выделилось $21 \%$ от ГЦ (6\% от ПС сырья) и лигнина $65 \%$ от содержания их в исходном сырье.

При последующем ФГ целлюлозосодержащего остатка с содержанием лигнина 8\% (ферментные препараты Celluclast 10-84 FPU/g целлюлозы и Novozyme188 с $\beta$-глюкозидазной активностью 346$480 \mathrm{CBU} / \mathrm{M}$, соотношение FPU/CBU $1-2: 1-1,75, \mathrm{t}=45^{\circ} \mathrm{C}, 48$ ч) достигнут выход глюкозы более 95\% от целлюлозы. Концентрация сахаров в гидролизате была 54,3 г/л. Получен выход этанола 0,46 г/г глюкозы или $90 \%$ от теоретического содержания ПС в древесине при продолжительности процесса брожения 48 ч. При $16 \%$ содержания лигнина в целлюлозосодержащем остатке степень конверсии целлюлозы в глюкозу составила 85-90\% при продолжительности процесса ФГ 24-48 ч. При содержании лигнина 46\% в целлюлозосодержащем остатке степень конверсии целлюлозы в глюкозу составила $42 \%$ при продолжительности процесса ФГ 48-96 ч [43].

При предобработке древесины хвойных пород с $\mathrm{SO}_{2}$ в одну ступень $\left(\mathrm{t}=210{ }^{\circ} \mathrm{C}, 5,5\right.$ мин, $\left.3,6 \% \mathrm{SO}_{2}\right)$ и в две ступени (стадия 1: $190{ }^{\circ} \mathrm{C}, 2$ мин, $3 \% \mathrm{SO}_{2}$; стадия 2: 210-220 ${ }^{\circ} \mathrm{C}, 5$ мин, $3 \% \mathrm{SO}_{2}$ ) выход ГЦ сахаров составил 52 и 95\% соответственно от теоретического их содержания. В случае с последующим ФГ целлюлозы получен общий выход сахаров 66 и $80 \%$ соответственно от ПС в сырье. При предобработке методом сернокислотного парового взрыва древесины хвойных пород в одну ступень $\left(215{ }^{\circ} \mathrm{C}, 1,7\right.$ мин, $\left.0,65 \% \mathrm{H}_{2} \mathrm{SO}_{4}\right)$ и в две ступени: (стадия 1: $180^{\circ} \mathrm{C}, 4$ мин, $2,66 \% \mathrm{H}_{2} \mathrm{SO}_{4}$; стадия 2: $210{ }^{\circ} \mathrm{C}, 1,5$ мин, 2,5\% $\mathrm{H}_{2} \mathrm{SO}_{4}$ ) выход ГЦ сахаров был 84 и $82 \%$ соответственно от теоретического. В случае с последующим ФГ целлюлозы получен общий выход сахаров 75 и $82 \%$ соответственно от ПС в сырье [41]. 
Результаты предобработки древесной биомассы методом парового взрыва с $\mathrm{SO}_{2}$ и биоконверсии полученных продуктов

\begin{tabular}{|c|c|c|c|c|c|c|c|c|c|c|c|c|c|}
\hline \multicolumn{7}{|c|}{ Стадия предобработки, условия гидролиза и промывки } & \multicolumn{2}{|c|}{ Ферментативный гидролиз } & \multicolumn{2}{|c|}{ Общий выход сахаров, \% } & \multicolumn{2}{|c|}{ Ферментация } & \multirow{3}{*}{ 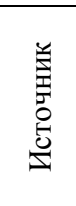 } \\
\hline \multirow[b]{2}{*}{ Вид сырья } & \multirow[b]{2}{*}{$\mathrm{t},{ }^{\circ} \mathrm{C}$} & \multirow[b]{2}{*}{$\begin{array}{c}\mathrm{SO}_{2} \\
\%\end{array}$} & \multirow[b]{2}{*}{$\begin{array}{c}\text { Время, } \\
\text { мин }\end{array}$} & \multirow[b]{2}{*}{ Промывка } & \multicolumn{2}{|c|}{ Гидролизат и промывные воды } & \multirow[b]{2}{*}{ условия } & \multirow{2}{*}{$\begin{array}{c}\text { степень } \\
\text { конверсии } \\
\text { целлюлозы, } \\
\text { \% }\end{array}$} & \multirow[b]{2}{*}{ от ПС сырья } & \multirow[b]{2}{*}{ от a.c.c. } & \multirow[b]{2}{*}{ условия } & \multirow{2}{*}{$\begin{array}{l}\text { выход эта- } \\
\text { нола, \% от } \\
\text { теоретиче- } \\
\text { ского и др. }\end{array}$} & \\
\hline & & & & & $\begin{array}{c}\text { моносахара, \% } \\
\text { от сахаров }\end{array}$ & $\begin{array}{c}\text { выход } \\
\text { сахаров, \% от } \\
\text { ГЦ }\end{array}$ & & & & & & & \\
\hline 1 & 2 & 3 & 4 & 5 & 6 & 7 & 9 & 10 & 11 & 12 & 13 & 14 & 15 \\
\hline \multicolumn{14}{|c|}{ Хвойные породы } \\
\hline Смесь & 187 & 2,0 & 2,0 & водой & 70 & 77 & & & - & - & - & - & 44 \\
\hline Смесь & 192 & 2,6 & 2,0 & водой & 100 & 89 & & & - & - & $\begin{array}{c}\text { P. stipitis R, } \\
372\end{array}$ & $\begin{array}{c}0,372 \text { л/кг } \\
\text { a.c.c. }\end{array}$ & 44 \\
\hline Ель & 200 & 2,5 & 5,0 & водой & - & 79 & - & - & 59 & 40 & - & - & 50 \\
\hline $\begin{array}{c}\text { Pinus Radi- } \\
\text { ata }\end{array}$ & 215 & 2,55 & 3,0 & водой & - & 88 & - & 82 & - & 57 & - & - & 47 \\
\hline Смесь & 210 & 3,6 & 5,5 & водой & - & 52 & - & - & 66 & - & - & - & $41^{* *}$ \\
\hline Ель & 215 & 3,0 & 5,0 & водой & - & 77 & - & - & 67 & 47,6 & & - & 50 \\
\hline Смесь & 195 & 3,91 & 2,38 & водой & 59 & $>90$ & - & - & - & - & & $64 \%$ & 48 \\
\hline Смесь & 175 & 4,5 & 7,5 & водой & 80 & 87 & - & - & - & - & - & - & 48 \\
\hline Сосна & 195 & 4,5 & 4,5 & водой & 75 & 100 & - & 73 & - & - & $\begin{array}{l}\text { S. cere- } \\
\text { visiae. }\end{array}$ & $86 \% ; 0,44 \Gamma / \Gamma$ & 48 \\
\hline $\begin{array}{l}\text { Douglas-fir, } \\
\text { лигнин 30\% }\end{array}$ & 195 & 4,5 & 4,5 & $\begin{array}{l}\text { водой, } \\
25^{\circ} \mathrm{C}\end{array}$ & 82 & $\begin{array}{c}127, \\
\text { пентоз-75 }\end{array}$ & $\begin{array}{c}\text { Celluclast } 20 \\
\text { FPU / геми- } \\
\text { целлюлозы, } \\
\text { Novozyme } 188 \text {, } \\
48 \text { ч, } 45^{\circ} \mathrm{C} \text {, } \\
\text { лигнин } 46 \%\end{array}$ & 63 & 82 & $\begin{array}{c}40,2 \\
10 \mathrm{FPU} / \mathrm{g}\end{array}$ & - & - & 43 \\
\hline Douglas-fir & 195 & 4,5 & 4,5 & $\begin{array}{c}1 \% \mathrm{H}_{2} \mathrm{O}_{2}, \\
\mathrm{pH} 11,5 \\
25^{\circ} \mathrm{C}, \\
12 \text { ч }\end{array}$ & 82 & $\begin{array}{c}127, \\
\text { пентоз-75 } \\
-\end{array}$ & $\begin{array}{c}\text { Celluclast } 20 \\
\text { FPU/г и Novo- } \\
\text { zymes } 18848 \text { ч, } \\
45{ }^{\circ} \mathrm{C}, \text { лигнин } \\
16 \%\end{array}$ & 90 & - & - & - & - & 43 \\
\hline Douglas-fir & 195 & 4,5 & 4,5 & $\begin{array}{c}1 \% \mathrm{H}_{2} \mathrm{O}_{2} \\
\mathrm{pH} 11,5 \\
80{ }^{\circ} \mathrm{C} \\
0,75 \text { ч }\end{array}$ & 82 & $\begin{array}{c}127, \\
\text { пентоз-75 }\end{array}$ & $\begin{array}{c}\text { Celluclast } 20 \\
\text { FPU/г и Novo- } \\
\text { zyme188 } 48 \\
\text { ч, } 45^{\circ} \mathrm{C}, \\
\text { лигнин } 8 \%\end{array}$ & 95 & 82 & $\begin{array}{c}56,4 \\
10 \mathrm{FPU} / \mathrm{g}\end{array}$ & $\begin{array}{c}\text { S. cere- } \\
\text { visiae, глю- } \\
\text { коза } 2 \%, 48 \\
\text { ч }\end{array}$ & $\begin{array}{c}90 \% \\
0,46 \text { г/г } \\
{[42]}\end{array}$ & 43 \\
\hline
\end{tabular}


Окончание таблицы

\begin{tabular}{|c|c|c|c|c|c|c|c|c|c|c|c|c|c|}
\hline 1 & 2 & 3 & 4 & 5 & 6 & 7 & 9 & 10 & 11 & 12 & 13 & 14 & 15 \\
\hline $\begin{array}{c}\text { Сосна } \\
\text { повре- } \\
\text { жденная }\end{array}$ & 200 & 4,0 & 5,0 & водой & 75 & 96 & $\begin{array}{c}2 \% \text { суспензия, } \\
\text { ФП Spezyme, } \\
\text { Novozymes } 188 \\
\text {, } 20 \mathrm{FPU} / \Gamma\end{array}$ & 84 & - & - & $\begin{array}{c}\text { S.cerevisiae, } \\
30^{\circ} \mathrm{C}, 48 \text { ч }\end{array}$ & $\begin{array}{c}72-73 \% \\
77 \% \mathrm{SSF}\end{array}$ & 45 \\
\hline $\begin{array}{c}\text { Сосна } \\
\text { повре- } \\
\text { жденная }\end{array}$ & 215 & 4,5 & 5,0 & водой & 78 & 86 & $\begin{array}{c}2 \% \text { суспензия, } \\
\text { ФП Spezyme, } \\
\text { Novozymes } 188 \\
\text {,20 FPU/г }\end{array}$ & 96 & - & - & $\begin{array}{c}\text { S.cerevisiae, } \\
30^{\circ} \mathrm{C}, 48 \text { ч }\end{array}$ & $72-73 \%$ & 45,46 \\
\hline \multicolumn{14}{|c|}{ Лиственные породы } \\
\hline Осина & 205 & 0,7 & 3,0 & водой & 57ксилоза & - & - & - & 68 & 45,0 & - & - & 27 \\
\hline Осина & 210 & 1,6 & 2,0 & $\begin{array}{l}2 \text {-х ступе- } \\
\text { ни водой }\end{array}$ & - & $\begin{array}{l}\text { сахаров - 95, } \\
\text { пентоз }-79,8\end{array}$ & $\begin{array}{c}\text { Культуральная } \\
\text { жидкость } \\
\text { Trichoderma } \\
\text { harzianum } \text { E58, } \\
100 \text { J.U./мл, } \\
30 \text { C, 3-5 сут. } \\
\end{array}$ & - & - & - & $\begin{array}{c}\text { Klebsiella } \\
\text { pneumoniae, } \\
\text { 3-4 суток, } \\
5 \%\end{array}$ & $\begin{array}{c}2,3- \\
\text { бутандиола } \\
\text { и этанола } \\
42 \%\end{array}$ & $39 * *$ \\
\hline Тополь & 190 & 3,0 & 5,0 & $\begin{array}{c}\text { окисли- } \\
\text { тельно- } \\
\text { щелочная }\end{array}$ & 57 & 96 & $\begin{array}{c}\text { Spezyme, GC- } \\
220 \text { и } \\
\text { Multifect, Хy- } \\
\text { lanase } \beta- \\
\text { глюкозидаза, } \\
15 \mathrm{FPU} / \Gamma\end{array}$ & - & 83 & 53,2 & $\begin{array}{c}\text { г.м.* S. cere- } \\
\text { visiae 424A } \\
(\mathrm{LNH}-\mathrm{ST}) \text {, } \\
28{ }^{\circ} \mathrm{C}, 48 \mathrm{ч}\end{array}$ & $\begin{array}{c}86,2 \% \\
0,46 \text { г/Г }\end{array}$ & 27,40 \\
\hline
\end{tabular}

* в гидролизном производстве выход этанола составляет 88\% от теоретического выхода или 0,444-0,487 г/Г глюкозы или 150-180 л/т а.с.с. [2],

** процесс оптимизирован, г.м. - генномодифицированный штамм дрожжей. 
Одним их крупномасштабных отходов растениеводства является солома злаковых культур. Делаются попытки использования данного метода кислотного парового взрыва для ее переработки с целью получения биотоплива. Наиболее подходящими для подготовки этих отходов к промышленному использованию являются передвижные установки получения гранул, например комплекс МЛГ-11 «Форвард» (насып-

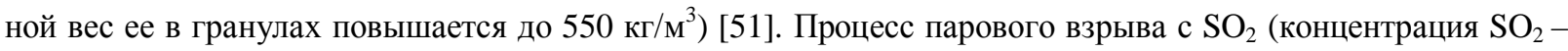
$6 \%, 190{ }^{\circ} \mathrm{C}$, время 5 мин) без промывки водой и отделения лигнина с последующим ФГ целлюлозы позволяет получить выход сахаров $81 \%$ от общего количества ПС. В процессе ферментации Sacharomyces cerevisiae степень конверсии сахаров в этанол составляет 90-96\% от теоретической $[52,53]$.

Таким образом, оптимальные технологические режимы метода предподготовки лигноцеллюлозной биомассы с $\mathrm{SO}_{2}$ или $\mathrm{H}_{2} \mathrm{SO}_{4}$ с паровым взрывом с последующим ФГ целлюлозы в условиях экспериментов характеризуются следующими параметрами:

- для хвойных видов древесины концентрация $\mathrm{SO}_{2}-4,0-4,5 \%, \mathrm{t}=195-200{ }^{\circ} \mathrm{C}, \tau=4,0-4,5$ мин с промывкой водой и щелочным раствором пероксида водорода, обеспечивают выход гемицеллюлозных сахаров не менее $80 \%$ и не менее $96 \%$ общих сахаров от теоретического содержания ГЦ в а.с.с. и для лиственных $-1,6 \% \mathrm{SO}_{2}, \mathrm{t}=210{ }^{\circ} \mathrm{C}, \tau=2$ мин; или $0,58 \% \mathrm{H}_{2} \mathrm{SO}_{4}, \mathrm{t}=210{ }^{\circ} \mathrm{C}, \tau=1,3$ мин, выход пентозанов с промывной водой составил 79,8 и 84,7\% соответственно от теоретического содержания их в исходном сырье;

- при ФГ суспензии целлюлозосодержащего остатка концентрацией $2 \%$ с использованием следующих ферментных препаратов: Celluclast с целлюлазной активностью 10-84 FPU/g целлюлозы и Novozyme 188 с $\beta$-глюкозидазной активностью 346-480 CBU/мл (оптимальная доза 20 FPU/г, соотношение FPU/CBU 1-2:1-1,75 в течение 48 ч) получен широкий диапазон результатов по степени конверсии целлюлозы в глюкозу от 63 до 90\% и более, при содержании лигнина в целлюлозосодержащем остатке 8 и $16 \%$ степень конверсии целлюлозы составила 95 и 90\% соответственно;

- общий выход сахаров в процессах предподготовки с последующей промывкой лигноцеллюлозного остатка водой и его ферментативного гидролиза составляет $82 \%$ от ПС сырья;

- при ферментации Saccharomyces cerevisiae на ферментативных гидролизатах получены выходы этанола в интервале от 72 до $90 \%$ от теоретического.

Основным достоинством непрерывного кислотно-катализируемого с паровым взрывом процесса предподготовки является то, что он обеспечивает высокий выход сахаров и позволяет экономить сырье и теплоэнергоресурсы. Экономия теплоэнергоресурсов в данном случае происходит за счет кратковременной температурной обработки, при которой происходит физическая и химическая деструкция растительной биомассы, позволяющая без существенных теплоэнергетических затрат провести ФГ и получить высокий выход сахаров.

Основной недостаток метода предподготовки: гидролизат ГЦ и промывные воды содержат олигосахара от 18 до 25\%, что является причиной разброса данных по выходу этанола от сахаров.

Для обеспечения стабильного выхода этанола до 90\% необходимо:

- ввести дополнительный процесс инверсии гидролизата ГЦ [5];

- стандартизировать размеры щепы.

Щелочные методы предобработки [2, 20, 54]. При щелочной обработке в основном используют такие реагенты, как едкий натр, едкий калий, гидроксиды кальция и аммония. Данный метод по классификации по относительной скорости движения фаз может быть как с избытком, так и с минимальным количеством жидкой фазы, чаще он бывает статическим и периодическим [2]. Щелочной метод более эффективный в отношении растворения ГЦ и лигнина, чем кислотный, и его относят к методам делигнификации и предобработки растительной биомассы к ФГ.

При щелочном гидролизе щелочь вызывает набухание поверхности биомассы. В результате увеличивается степень деполимиризации ПС и снижается индекс кристалличности целлюлозы. Эти процессы сопровождаются разрывом связей между лигнином и углеводами, разрушением структуры лигнина. Идет омыление эфирных связей, высвобождаются ГЦ и другие компоненты. Образуются уксусная и уроновые кислоты. Увеличивается пористость биомассы. Это позволяет повысить эффективность ФГ за счет большего контакта ФП с ПС и продуктами их частичного гидролиза $[54,55]$.

В одних источниках указывают, что данный метод выгоднее использовать для сельскохозяйственных видов лигноцеллюлозного сырья [56, 57], а едкий натр - для лиственной и хвойной древесины с содержанием лигнина ниже, чем 26\% [57]. В других источниках рекомендуют применять едкий натр для 
хвойных видов древесины, когда требуются экстенсивные выделительные операции для достижения эффективного ФГ [3, 58].

Известен многоступенчатый способ ФГ различных видов тонкоизмельченного ( $\mathrm{d}=1-120$ мкм) крахмалсодержащего сырья (отруби или мука, зерно или их смесь в любом соотношении), который проводили после щелочной обработки с едким калием (а.с.в. $-5-10 \% ; \mathrm{pH} 12-13, \mathrm{t}=90{ }^{\circ} \mathrm{C}, \tau=2$ ч, $\mathrm{PB}=0,35-$ 0,59\%). Процесс ФГ состоял из 4 стадий, аналогичных представленным выше [12, 20]. Это позволило выделить ГЦ в раствор. Достигнута высокая концентрация РВИ = 8\% в ферментолизате за счет более интенсивного метода подготовки. Оценка эффективности процесса по степени конверсии не представлена. Оценка эффективности всех процессов предподготовки, ФГ и выращивания смешанных культур на разбавленном субстрате сделана по сырому протеину в готовом белковом продукте при использовании смеси культур Saccharomyces cerevisiae и Trichosporon mycotoxininorans. В данном случае сырой протеин для ферментализатов различных видов пшеничного сырья отрубей (общие углеводы 42,1\%), дерти, муки (общие углеводы 88,5\%) при содержании в пульпе РВ 2,3; 2,6; 3,6\% (а.с.в. 3,95; 5,6; 4,9) составил (\%вес.): $35-$ 40; 45-50; 48-54 соответственно [20].

Если сравнивать эффективность двух следующих методов предподготовки отрубей по качеству кормового белкового продукта: первый с интенсивным измельчением и с последующим щелочным гидролизом и ФГ ПС (сырой протеин 35-40\%) и второй ГТДО с измельчением в РПА и термостабильной $\alpha$-амилазой (сырой протеин 39,8\% [2]), то разницы не видно. Но в первом случае концентрация РВ 2,3\% за счет использования ФП с глюкоамилазной активностью. Во втором случае глюкоамилазы не применяли, а добавляли сернокислотный гидролизат зерна, концентрация РВИ =1,77\%.

Сырой протеин в готовом продукте существенно выше при использовании сырья с содержанием углеводов, чем в отрубях. При сравнении следующих методов на основе муки: с тонким измельчением и щелочной обработкой с последующим ФГ ПС (сырой протеин 48-54\%) и метода без тонкого измельчения сырья и без ФГ ПС (с использованием послеспиртовой барды и 5\% муки, сырой протеин 46,0-46,8\% [13]) видно явное преимущество первого метода. Преимущество этого метода также состоит в экономии тепла при подготовке сырья к ФГ и проведения его на более концентрированной пульпе.

В России способ щелочной обработки зерновой соломы используют для получения кормов, за рубежом ведутся исследования по разработке метода предподготовки зерновой соломы к ФГ с последующим получением биоэтанола. Исследована эффективность влияния различных щелочных растворов на степень делигнификации и растворения гемицеллюлоз соломы пшеницы. Установлено, что оптимальными являются следующие условия: $1,5 \%$ гидроксида натрия, время 144 ч, $\mathrm{t}=20{ }^{\circ} \mathrm{C}$. При этом растворяются $60 \%$ лигнина и $80 \%$ гемицеллюлоз $[55,57,59]$.

Технологическая схема при щелочном методе предподготовки древесного сырья к ФГ состоит из следующих стадий:

1) лигноцеллюлозную биомассу, пар и реагенты подают в гидролизаппарат, где осуществляют ряд операций: прогрев; гидролиз гемицеллюлозных ПС и растворение лигнина; отделение гемицеллюлозного гидролизата; промывка водой и отделение промывных вод от целлюлозосодержащего остатка; отжим; выстрел целлюлозного остатка;

2) испарение гидролизата и промывных вод;

3) ФГ целлюлозосодержащего остатка;

4) корректировка $\mathrm{pH}$ смеси гидролизатов;

5) декантация или центрифугирование для осветления смеси ферментативного гидролизата и нейтрализованного гемицеллюлозного гидролизата и для отделения лигнина;

6) ферментация рекомбинантного штамма дрожжей Sacharomyces cerevisiae, сбраживающего пентозы и гексозы, на объединенном осветленном нейтрализованном гидролизате.

Щелочной метод был использован для хвойных видов древесины [60]. При щелочной предобработке с едким натрием $\left(15 \% \mathrm{NaOH}, \tau=180\right.$ мин, $\mathrm{t}=110^{\circ} \mathrm{C}$;) выход лигнина составил $84 \%$, выход сахаров не представлен. Биоконверсия целлюлозы в глюкозу была 90 и 100\% с расходом целлюлазы 20 и 40 ед. фильтровальной бумаги /г целлюлозы соответственно за время 48 ч [59].

Проведены исследования по повышению эффективности ФГ биомассы сосны и березы после предварительной обработки их окислительно-щелочным методом $\left(\mathrm{t}=120-170{ }^{\circ} \mathrm{C}\right.$, концентрация пероксида $0,5-$ 5\%). Установлено, что полная делигнификация наблюдается при концентрации пероксида водорода $5 \%$. 
Для эффективного ФГ твердого остатка (ферментный препарат из Trichoderma viride и Aspergillius foetidus при активности эндоглюконазы 1 ед./мл, целлобиазы 2 ед./мл и ксиланазы 0,6 ед./мл при $\mathrm{t}=46{ }^{\circ} \mathrm{C}$ с ацетатным буфером концентрацией 0,05 моль/л, время 48 ч, ГМ 20) достаточно следующих условий делигнификации: $\mathrm{t}=170{ }^{\circ} \mathrm{C}$ и концентрация пероксида водорода $1,4 \%$. Выход РВ от теоретического содержания составляет 64\% для березы (сумма полисахаридов в древесине - 63,6\%) и 41\% для сосны $(65,8 \%$ ) [61].

Известен ряд работ по сравнительному исследованию разных методов конверсии древесных отходов [3, 39, 40, 42, 43]. Проведены сравнения эффективности следующих способов предобработки биомассы тополя: паровзрывная обработка с $\mathrm{SO}_{2}\left(\mathrm{SO}_{2} 3,0 \%, \mathrm{t}=190{ }^{\circ} \mathrm{C}, 5\right.$ мин, концентрация а.с.с. 15\%), паровая обработка с кислотами в пилотном реакторе Sunds $\left(\mathrm{H}_{2} \mathrm{SO}_{4} 2,0 \%\right.$ от а.c.c., $\mathrm{t}=190{ }^{\circ} \mathrm{C} ; 1,1$ мин; концентрация a.c.c. $15 \%$ ), окислительно-щелочная с известью (Lime: известь 20,0\%, $\mathrm{t}=160{ }^{\circ} \mathrm{C}, 5$ мин, концентрация а.с.с. $39 \%$, кислородное избыточное давление); паровзрывная с гидроксидом аммония (AFEX) [40]. При выше указанных процессах предобработки и ФГ целлюлозсодержащего остатка с использованием следующих ФП: Spezyme CP с целлюлазной активностью 59 FPU/мл, GC-220 с целлюлазной активностью 89 FPU/мл и Multifect Xylanase c 41 мг протеина/мл, $\beta$-глюкозидаза с 85 мг протеина/мл (соотношение $\beta$-глюкозидазы к целлюлазе 2,0 : 1, расход целлюлазы $15 \mathrm{FPU} / \Gamma$ глюкана) общий выход сахаров от теоретического содержания полисахаридов составил 95,9, 82,8, 91,3, 52,8\% соответственно. Для получения этанола был использован рекомбинантный штамм дрожжей Saccharomyces cerevisiae $424 \mathrm{~A}(\mathrm{LNH}-\mathrm{ST})\left(\mathrm{t}=28,5{ }^{\circ} \mathrm{C}\right.$, время 48 ч), сбраживающий пентозы и гексозы. Выход этанола от теоретического выхода (теоретический выход от сброженных сахаров - 0,51) и концентрация этанола на данных субстратах были следующими: $86,2 \%$ и 25,9 г/л; 81,4\% и 26,4 г/л; $100 \%$ и 39,9 г/л; 88,6\% и 35,5 г/л соответственно [40].

В указанных ранее условиях при переработке биомассы тополя установлено, что по показателю выхода сахаров преимущества на стороне следующих способов предобработки: паровзрывного с $\mathrm{SO}_{2}$ и окислительно-щелочного с известью (Lime); а по концентрации этанола преимущества на стороне щелочных методов. Отмечено, что при окислительно-щелочном методе с известью (Lime) наблюдается забивание оборудования.

Имеются данные в виде кинетических кривых выхода глюкозы от целлюлозосодержащей массы, полученной разными методами делигнификации [3, 39, 42, 43]. По снижению концентрации остаточного лигнина способы делегнификации можно расположить в следующий ряд: 1 - с уксусной кислотой (остаточный лигнин 18,7\%); 2 - органосольвентная с серной кислотой $(18,4 \%) ; 3$ - с уксусной и соляной кислотами с последующей щелочной обработкой $(17,1 \%) ; 4$ - паровой взрыв с $\mathrm{SO}_{2}$ с последующей окислительнощелочной обработкой $(14,8 \%) ; 5$ - паровой взрыв с SO 2 с последующей промывкой целлюлозосодержащего остатка $1 \%$ водным раствором пероксида водорода ( $\mathrm{pH} 11,5 ; \mathrm{t}=80{ }^{\circ} \mathrm{C}$, время 45 мин) в 3 ступени (8\%). При этом четкой зависимости степени конверсии целлюлозы в глюкозу при ФГ с разными методами предобработки от содержания лигнина не выявлено. За 48 ч ФГ максимальная степень конверсии целлюлозы в глюкозу $90 \%$ получена во втором случае, в случае 4 - 70\%, в случае 5 - 95\%. При использовании остальных способов делигнификации хвойной древесины с последующим ФГ степени конверсии целлюлозы ниже [3, 37]. Показано преимущество органосольвентной технологии [37], в случае 5 из-за многоступенчатости процесса авторы $[42,43]$ не рекомендуют его к использованию.

Сравнивая результаты биоконверсии, можно сделать вывод, что общий выход сахаров в процессе предподготовки и ФГ не менее 90\% обеспечивают следующие процессы предподготовки древесины: окислительно-щелочной с известью (Lime) $(91,3)$; паровзрывной с $\mathrm{SO}_{2}$ (95,9\%). В процессе брожения выход этанола в этих процессах составил 100 и 86,2\% соответственно. Выход сахаров в процессе ФГ около $90 \%$ обеспечивают следующие процессы: органосольвентный с серной кислотой и промывкой твердого остатка с содержанием лигнина 18,4\% (90\%); паровзрывной с $\mathrm{SO}_{2}$ с последующей промывкой целлюлозосодержащего остатка $1 \%$ водным раствором пероксида водорода с содержанием лигнина $8 \%$ (более $95 \%$ ) и $16 \%$ (90\%). При щелочном методе делигнификации с едким натрием выход сахаров при ФГ для хвойных видов древесины составляет не менее $90 \%$.

Предобработка механохимическими методами без отделения лигнина. В данной работе рассматриваются два следующих механохимических метода гидролиза биомассы древесины без отделения лигнина: бисульфитный (SPORL) и сернокислотный с использованием дефибрационного метода размола щепы. Согласно классификации методов конверсии растительного сырья по относительной скорости движения фаз данные методы относят к динамическим непрерывным процессам по жидкой и твердой фазам [2]. 
Бисульфитный процесс предобработки (SPORL) [3, 25, 58, 62-64]. Бисульфитный процесс предобработки (SPORL) лигноцеллюлозного сырья состоит из нескольких следующих технологических стадий $[25,63]$ :

1) в гидролизер непрерывного действия подают древесную биомассу, пар и 1-4\% водный раствор бисульфита натрия (магния, кальция и др.) для лиственного сырья и 6-9\% - для хвойного $\left(\mathrm{t}=160-190{ }^{\circ} \mathrm{C}\right.$, pH 2-3, время 10-30 мин, ГМ 1,5-3; концентрация серной кислоты 1,84-3,7\%);

2) тонкое измельчение прогидролизованной древесной биомассы в дисковой мельнице до частиц диаметром до 1 мм с добавлением воды (содержание лигнина в прогидролизованной биомассе составляет 26-39\% вес. от а.с.с., или 25,6-38\% вес. от влажного сырья) [62, 63];

3) отделение твердого остатка от гемицеллюлозного гидролизата на прессе;

4) вакуум-упаривание гемицеллюлозного гидролизата;

5) смешение упаренного гемицеллюлозного гидролизата с прогидролизованной биомассой;

6) ФГ целлюлозосодержащего твердого остатка одновременно с ферментацией рекомбинантного штамма дрожжей Saccharomyces cerevisiae YRH400 на сгущенном гемицеллюлозном гидролизате.

Представлены материальные балансы компонентов сред по стадиям различных технологических схем получения этанола из древесной щепы [25]. Выход сахаров в растворе и твердом остатке после процесса предподготовки составляет 81-93 вес.\% от ПС в сырье. При этом степень растворения лигнина составляет 18-28,3\% от теоретического содержания его в сырье [3, 25].

Степень конверсии целлюлозы в глюкозу при ФГ (загрузка ферментов: целлюлазы для лиственного сырья 7,5 и для хвойного от 14,6-15 FPU/г субстрата, $\beta$-глюкозидазы 22,5 CBU/г субстрата) может быть достигнута до 90\% за 24 ч и почти до 100\% за 48 ч. Выход глюкозы - 38 и $40 \%$ от а.с. древесины соответственно. Установлено, что наибольший выход сахаров и минимальные энергетические затраты наблюдаются в случае использования способа предобработки SPORL c pH 1,9 в сравнении со способом предобработки с разбавленными кислотами с $\mathrm{pH}$ 1,1. При совместной ферментации штамма Saccharomyces cerevisiae YRH400 $\left(35^{\circ} \mathrm{C}\right.$ and pH 5,5), сбраживающего пентозы и гексозы, и ФГ (Cellulase (CTec2) 9 FPU или 0,06 мл/Г необработанной древесины) на субстрате с содержанием твердого вещества 8-10\% получен выход этанола 0,33-0,40 г/г сахара за 48 ч, или 243-287 л/т а.с.с. Концентрация этанола составила 40-45,9 г/л $[3,64]$. При концентрации твердого вещества $18 \%$ в процессе предобработки получена максимальная концентрация этанола 45-55 г/л за время 100-120 ч [25]. При раздельных процессах ФГ и ферментации после ФГ измельченной биомассы ели получена степень конверсии целлюлозы более $90 \%$ за 48 ч и выход этанола 0,35-0,42 г/г сахара, или 238-270 л/т а.с.с. [25, 58].

Таким образом, уровень выхода этанола от а.с.с. незначительно выше при совместном проведении процессов ФГ и ферментации, но наблюдается увеличение продолжительности процесса при совместной биоконверсии в сравнении с отдельной ферментацией [3].

Можно отметить следующие основные достоинства процесса SPORL:

- проведение предобработки с низким гидромодулем 1,5-3,0 и возможность переработки субстрата концентрацией до $18 \%$ по твердому веществу с получением концентрации этанола в бражке до 55 г/л дают экономию теплоресурсов в процессах гидролиза и дистилляции этанола, позволяют снизить количество сточных вод и повысить производительность оборудования;

- отсутствие стадий выделения лигнина перед процессом ФГ;

- присутствие лигносульфонатов снижает адсорбцию ферментов лигнином и позволяет повысить эффективность ФГ, степень конверсии целлюлозы в глюкозу при ФГ составляет более $90 \%$ в присутствии лигнина в количестве около $30 \%$;

- производство биотоплива на основе технологии с переработкой концентрированного субстрата возможно без организации замкнутого цикла водопользования;

- генномодифицированный штамм дрожжей Saccharomyces cerevisiae YRH400 обеспечивает выход этанола на уровне выхода в гидролизном производстве и в 1,5 раза выше в пересчете на а.с.с. за счет сбраживания пентозных сахаров [3, 25].

Основные недостатки способа SPORL: использование неосветленного питательного субстрата в процессе брожения ведет к снижению выхода этанола, невозможности проведения рециркуляции дрожжей и выведения мертвых дрожжей, забиванию аппаратуры и коммуникаций.

Кислотно-каталитический метод предподготовки с УГР. Исследован кислотно-каталитический метод предобработки биомассы древесного сырья с одновременным измельчением в размольной камере 
в виде двух дисков. Разработана комплексная технологическая схема получения следующих продуктов: кормовой осахаренной древесины, этанола и кормовых дрожжей. Проведены опытно-промышленные испытания установок горячего размола (УГР) с подогревом в две ступени (предварительный прогрев при $\mathrm{t}=135-180{ }^{\circ} \mathrm{C}$ в течение 5 мин и прогрев в процессе измельчения в течение 15 сек), смонтированных на пяти промышленных предприятиях России. УГР применяют в России в производстве древесноволокнистых плит. Впервые предложение по использованию данных установок в гидролизном производстве сделали В.В. Коротков, А.В. Владимирский и Е.Д. Гельфанд [24]. Научно-исследовательские и опытнопромышленные работы по проверке возможности использования УГР были проведены Н.А. Жуковым и группой авторов в ВятГУ (Киров) под руководством академиков РАМН и РАСХН В.А. Быковым и РАСХН Л.К. Эрнста [24, 65].

Установлено, что выход моносахаров и олигосахаров составляет 25-30\% от а.с.с. при расходе кислоты $8-12 \%$ от а.c.c. и $\mathrm{t}=165-180{ }^{\circ} \mathrm{C}$, а также $12-17 \%$ от а.c.c. при расходе кислоты $1-4 \%$ от а.с.с. и $\mathrm{t}=150{ }^{\circ} \mathrm{C}$. Проверена возможность ФГ гидролизатмассы $[3,24,65]$.

Впервые в России в ВятГУ разработаны два непрерывных процесса с использованием УГР, состоящие из паровой камеры и дисковой мельницы. Один способ - двухстадийный гидролиз древесного сырья с получением этанола и кормовых дрожжей. Второй способ - одностадийный гидролиз с получением фурфурола, кормового белка и этанола. Основной недостаток метода, не позволяющий внедрение УГР в гидролизном производстве, - это то, что данные установки не предназначены для кислотного гидролиза и выполнены из некислотостойкой стали.

Кислотно-каталитический метод предподготовки отходов древесины с УГР с последующим ФГ целлюлозы в лигноцеллюлозном остатке с использованием элементов технологии SPORL (с бисульфитом 8\%, $\mathrm{H}_{2} \mathrm{SO}_{4} 3,68 \%$; pH 1,9-3; ГM 1,5-3; $\mathrm{t}=160-190{ }^{\circ} \mathrm{C}, 10-30$ мин) можно рекомендовать к промышленному внедрению на гидролизных предприятиях России после проведения дополнительных исследований.

\section{Bblвodbl}

Оптимальным и дешевым методом предподготовки крахмалсодержащего сырья (отруби, некондиционная мука и другие зерноотходы) к ФГ является следующая технология: тонкое измельчение сырья; гидротермодинамическая обработка (ГТДО) при следующем технологическом режиме: а.с.в. не менее $15 \%$; $\mathrm{t}=86-100{ }^{\circ} \mathrm{C}$, время выдержки при этой температуре не более 1 ч с термостабильным ферментным препаратом, содержащим $\alpha$-амилазу (Зимаджунт 340С* или Амилаза НТ-4000 или Амилекс 4Т). Эффективность последующего ФГ частично гидролизованного крахмала и некрахмалистых полисахаридов крахмалсодержащего сырья обеспечивает следующий комплекс ферментных препаратов: Глюковамарин, GC 220, обладающий целлюлазной, целлобиазной, ксиланазной и $\beta$-глюканазной активностями, и Novozymes 188 , coдержащий целлобиазу.

Процесс тонкого измельчения растительной биомассы необходимо оптимизировать для каждого отдельного случая в зависимости от вида растительного сырья, технологии предобработки и механизмов измельчения. Для лигноцеллюлозного сырья проводить его надо после или одновременно с термохимической обработкой или одновременно с ферментативной предобработкой.

По представленным данным видно, что в процессе ФГ целлюлозной массы концентрацией $2 \%$ при расходе целлюлазы не менее 20-25 FPU/г целлюлозы с ферментными препаратами Celluclast 20 FPU/г и Novozyme188 или Spezyme CP, GC-220 (15 FPU/g), Multifect Xylanase получен общий выход сахаров не менее $90 \%$ от теоретического со всеми рассмотренными способами предподготовки в соответствующих условиях:

- органосольвентный с $\mathrm{H}_{2} \mathrm{SO}_{4}$ 0,1-1,1\%, этанол 55-75\%, ГМ 7, t = 170-180 ${ }^{\circ} \mathrm{C}, 55-77$ мин;

- паровой взрыв с $\mathrm{SO}_{2} 4,5 \%, \mathrm{t}=195^{\circ} \mathrm{C}, 4,5$ мин с промывкой водой и окислительно-щелочным раствором;

- SPORL с бисульфитом 8\%, $\mathrm{H}_{2} \mathrm{SO}_{4} 3,68 \%$; $\mathrm{pH}$ 1,9-3; ГM 1,5-3; t = 160-190 ${ }^{\circ} \mathrm{C}, 10-30$ мин;

- щелочной с $15 \% \mathrm{NaOH}, \mathrm{t}=110{ }^{\circ} \mathrm{C}, 3$ ч;

- окислительно-щелочной (с кислородом и известью) (Lime: известь 20,0\%, t $=160{ }^{\circ} \mathrm{C}, 5$ мин, концентрация а.с.с. $39 \%$ ). 
Перспективными из них можно считать первые три, а также кислотно-каталитический с УГР [3, 19], при этом в первых двух способах допускается содержание лигнина в целлюлозосодержащем остатке до 16$18 \%$, а в третьем - до $30 \%$.

Преимущество процессов предподготовки определяет их экономическая эффективность и обеспечение экологических требований [3].

Проведен экономический анализ трех способов предподготовки по затратам энергии: парового взрыва, органосольвентный и SPORL [50]. При методе SPORL выше энергетические затраты за счет введения процесса тонкого измельчения пульпы в сравнении с органосольвентным способом предподготовки сырья. Но за счет того, что выход сахаров на 1 т сырья выше, выше и выход сахаров на единицу затраченной энергии. Авторами показано экономическое преимущество метода SPORL [50].

Требуется проверка следующих методов конверсии древесного сырья: кислотно-каталитического органосольвентного, кислотно-каталитического с установкой горячего размола (УГР) и с элементами бисульфитного SPORL метода и проведение экономического анализа их в сравнении с гидролизным производством. А также необходимо разработать эффективные процессы ФГ и ферментации продуцентов этанола с рекомбинатным штаммом дрожжей и бутанола с использованием субстратов с концентрацией 10-18\% а.с.в.

Требуется обобщение данных по конверсии лигноцеллюлозного однолетнего растительного сырья.

\section{Список литературь}

1. Яроцкий С.В., Сушкова В.И., Синеокий С.П., Лукина Г.П. Экономический анализ производства биобутанола и перспективы его развития. М. Деп. в ВИНИТИ 10.04.2008, №308. 65 с.

2. Сушкова В.И., Воробьева Г.И. Безотходная конверсия растительного сырья в биологически активные вещества. М., 2008. 215 с.

3. Сушкова В.И., Устюжанинова Л.В. Методы подготовки отходов производств лесопиления и деревообработки к биоконверсии в биорастворители. М. Деп. в ВИНИТИ 1.08.2013, №228-В2013. 95 с.

4. Сушкова В.И., Устюжанинова Л.В. Ферментативный гидролиз отходов от переработки растительного сырья // Общество, наука, инновации (НТК-2011): материалы Всероссийской научно-технической конференция. Киров, 2014. С. 20-23.

5. Шарков В.И., Сапотницкий С.А., Дмитриева О.А., Туманов И.Ф. Технология гидролизных производств. М., 1973. $408 \mathrm{c}$.

6. Шарков В.И., Куйбина Н.И. Химия гемицеллюлоз. М., 1972. 440 с.

7. Холькин Ю.И. Технология гидролизных производств. М., 1989. 496 с.

8. Сушкова В.И., Устюжанинова Л.В. Биоконверсия биомассы кукурузной кочерыжки с ферментными препаратами // Общество, наука, инновации (НТК-2011): материалы Всероссийской научно-технической конференция. Киров, 2012. С. 16-17.

9. Лихтенберг Л.А. Производство спирта из зерна. Приготовление замеса и его обработка // Пищевая промышленность. 1997. №3. С. 22-25.

10. Сушкова В.И. Процесс ферментации. Биореакторы. Практикум к курсовому и дипломному проектированию. Учебное пособие. Киров, 2006. 63 с.

11. Устюжанинова Л.В., Сушкова В.И. Получение кормовых пробиотиков на основе ферментолизата отрубей // Новые достижения в химии и химической технологии растительного сырья. Барнаул, 2012. С. 523-524.

12. Патент №2478701 (РФ). Штамм дрожжей Saccharomyces cerevisiae, обладающий амилазной активностью для получения кормового белкового продукта, и способ производства кормового белкового продукта / Г.И. Воробьева, А.Е. Сычев, А.И. Заикина, Р.А. Рогачева, Г.В. Чалков / 2013.

13. Патент №215287 (РФ). Способ получения белковой кормовой добавки / А.Ю. Винаров, А.И. Заикина, А.П. Захарычев, Т.Е. Сидоренко, Ю.В. Ковальский, Р.А. Рогачева, Л.В. Зорина / 2000.

14. Синицын А.П., Гусаков А.В., Черноглазов В.М. Биоконверсия лигноцеллюлозных материалов. М., 1995. $220 \mathrm{c}$.

15. Дедков В.Н. Разработка биотехнологии кормового белка из растительного сырья : дис. ... канд. техн. наук. Воронеж, 2014. $23 \mathrm{c}$.

16. Guoce Yu., Shinichi Yano, Hiroyuki Inoue, Seiichi Inoue, Takashi Endo, Shigeki Sawayama. Pretreatment of Rice Straw by a Hot-Compressed Water Process for Enzymatic Hydrolysis // Applied Biochemistry and Biotechnology. 2010. Vol. 160. N2. Pp. 539-551.

17. Weil J.R., Sarikaya A., Rau Sh-L., Goetz J., Ladisch Ch.M., Brewer M., Hendrickson R., Ladisch M.R. Pretreatment of corn fiber by pressure cooking in water // Applied Biochemistry and Biotechnology. 1998. Vol. 73. N1. Pp. 117.

18. Lei H., Cybulska I., Julson J. Hydrothermal Pretreatment of Lignocellulosic Biomass and Kinetics // Journal of Sustainable Bioenergy Systems. 2013. Vol. 3. N4. Pp. 250-259. 
19. Harmsen P.F.H., Huijgen W.J.J., López L.M. Bermudez. Literature Review of Physical and Chemical Pretreatment Processes for Lignocellulosic Biomass. Preface. ECN-E--10-013. 2010. (Netherlands). [Электронный ресурс]. URL: http://www.ecn.nl/docs/library/report/2010/e10013.pdf

20. Воробьева Г.И., Заикина А.И., Сычев А.Е. и др. Биокатализ растительных отходов путем ферментолиза и выращивания смешанной культуры микроорганизмов для получения кормовых белковых продуктов // Перспективные ферментные препараты и биотехнологические процессы в технологиях продуктов питания и кормов : сборник научных трудов. М., 2014. С. 323-332.

21. Синицын А.П., Попов В.О., Синицына О.А., Рожкова А.М., Федорова Е.А., Морозова В.В., Зоров И.Н., Гусаков А.В., Семенова М.В., Кондратьева Е.Г., Саттругдинов А.Л., Короткова О.Г., Осипов Д.О., Беккаревич А.О., Матыс В.Ю., Бубнова Т.В., Кошелев А.В., Окунев О.Н Высокоэффективный комплекс целлюлаз Penicillium для осахаривания лигноцеллюлозной биомассы. [Электронный pecypc]. URL: http://biorosinfo.ru/Vcongress/Sinizin.pdf

22. Морозов Э.А., Рязанова Т.В., Еременко О.Н. Влияние размола на полисахаридный комплекс древесины // Молодые ученые в решении актуальных проблем науки: сб. научн. тр. Владикавказ, 2010. Т. 2. С. 39-43.

23. Zang Meng, Song Xiiaoxu, Deines T.W., Pei Z.J., Wang Donghai. Biofuel manufacturing from woody biomass: effects of sieve size used in biomass size reduction // Journal of Biomedicine and Biotechnology. 2012. Vol. 2012. 9 p.

24. Жуков Н.А. Теоретические основы и технологические принципы непрерывной конверсии растительного сырья: автореф. дис. ... д-ра техн. наук. Киров, 2001. 45 с.

25. Zhu J.Y. SPORL technology platform for biofuel production from woody biomass: An Update // Tappi IBBC. 2011. 28 p.

26. Zhu J.Y., Wang G.S., Pan X.J., and et. al. Specific surface to evaluate the efficiencies of milling and pretreatment of wood for enzymatic saccharification // Chemical Engineering Science. 2009. Vol. 64. N3. Pp. 474-485.

27. Голязимова О.В. Механическая активация ферментативного гидролиза целлюлозы и лигноцеллюлозных материалов : автореф. дис. ... канд. хим. наук. Новосибирск, 2010. 20 с.

28. Iakovlev M., Pääkkönen T., van Heiningen A. Article in press - uncorrected proof. Kinetics of $\mathrm{SO}_{2}$-ethanol-water pulping of spruce // Holzforschung. 2009. Vol. 63. pp. 779-784.

29. Гермер Э.И. Химизм и катализ кислородно-щелочной делигнификации : дис. ... д-ра хим. наук. СПб, 1999. 287 с.

30. Сажин А.А. Исследование физико-химических процессов делигнификации древесины в системе этанол - вода - уксусная кислота и пролучение материалов на основе органосольвентных полуфабрикатов : дис. ... канд. техн. наук. Йошкар-Ола, 2004. 20 c.

31. Stockburger Pad. An overview of near-commercial and commercial solvent-based pulplng processes // Tappi Journal. 1993. Vol. 76. N6. Pp. 70-74.

32. Engvist E. Ivpregnation, vapor phase and methanol as means of intensivying the softwood kraft pulping process: diss. ... doct. of science. Helsinki, Espoo. 2006.

33. Фам Ван Коонг. Натронная варка древесины сосны в системе изобутиловый спирт - вода : автореф. дис. ... канд. техн. наук. Архангельск, 1995. 18 с.

34. Patent 4767500 (US). Sulfite cooking methanol for the production of cellulose from materials containing lignocellulose with recovery of the cooking chemicals / Rufolf Patt, Reinbek, Othar Kordsachia, Ostseinbek / 1988.

35. Black N.P. ASAM alkaline sulfite pulping process shows potential for large scale application // Tappi Journal. 1991. Vol. 74. N4. Pp. 129-132.

36. Патент №2135665 (РФ). Способ получения целлюлозной массы / Х.-Л. Шуберт, М. Миридит, М.Х. Зиннер, О. Кордзахиа / 1999.

37. Pan X.J., Arato C., Gilkes N., Gregg David, Mabee Warren, Pye Kendall, Xiao Zhizhuang, Zhang Xiao, Saddler John. Biorefining of softwoods using ethanol organosolv pulping: preliminary evalution of pricess streams for manufacture of fuel-grade ethanol and co-products // Biotechnology and Bioengineering. 2005. Vol. 90. N4. Pp. 473-481.

38. Белуза Я.М. Деструкция целлюлозосодержащих материалов при воздействии сдвиговых деформаций и высокого давления и технология кормовых добавок : автореф. дис. ... канд. техн. наук. Л., 1987. 19 с.

39. Mackie K.L., Brownell H.H., West K.L., Saddler N. Effect of sulfur dioxide and sulfuric acid on steam explosion of aspen wood // Journal of Chemistry and Technology. 1985. N5(3). Pp. 405-425.

40. Wyman C.E., Date D.E., Elander R.T. Comparative sugar recovery and fermentation data following pretreatment of poplar wood by leading technologies // Biotechnology Progress. 2009. Vol. 25. Pp. 333-339.

41. Galbe M., Zacchi G. A review of the production of ethanol from softwood // Appl Microbiol Biotechnol. 2002. Vol. 59. Pp. 618-628.

42. Mabee W.E., Grecc D.J., Arato C., Berlin A., Bura R., Gilkes N., Mirochnik O., Pan X., Pye E.K., Saddler J.N. Updates on Softwood-to-Ethanol Process Development // Applied Biochemistry and Biotechnology. 2006. Vol. 129. N1-3. Pp. 55-70.

43. Yang B., Boussaid A., Mansfield S.D., Gregg D.J., Saddler J.N. Fast and efficient Alkaline Peroxide Treatment to enchance the Ensimatic digestibility of steam-exploded softwood substrates // Biotechnology and Bioengineering. 2002. Vol. 77. Pp. 678-684.

44. Wayman M., Parekh S., Chornet E. $\mathrm{SO}_{2}$ - catalyzed prehydrolysis coniferous wood for etanol production // Biotechnology Letters. 1986. Vol. 8. N10. Pp. 749-752.

45. Ewanick S.M., Bura R., Saddler J.N. Acid-catalyzed steam pretreatment of lodgepole pine and subsequent enzymatic hydrolysis and fermentation to ethanol // Biotechnology and Bioengineering. 2007. Vol. 98. N4. Pp. 737-746. 
46. Ewanick S.M. Bioconversion of mountain pine beetle-killed lodgepole pine to ethanol. A thesis submitted in partial fulfillment of the requirements for the degree of master of science. 2006. $128 \mathrm{p}$.

47. Clark T.A., Vackie K.L. Steam explosion of softwood Pinus Radiata with Sulphur Dioxide addition. 1. Pricess optimization // Journal of Wood Chemistry and Technology. 1987. Vol. 7. N3. Pp. 373-403.

48. Boussaid A, Robinson J, Cai Yj and et. al. Fermentability of the hemicellulose-derived sugars from steam-exploded softwood (douglas fir) // Biotechnol Bioeng. 1999. Vol. 5. N64(3). Pp. 284-289.

49. Boussaid_A, Cai_Y, Robinson J., Cai Y.J., Gregg D.J., Saddler J.N. Sugar recovery and fermentability of hemicellulose hydrolysates from steam-exploded softwoods containing bark // Biotechnology Progress. 2001. Vol. 17. N5. Pp. 887-892.

50. Zhu J.Y., Pan X.J. Woody biomass pretreatment for cellulosic ethanol production: Technology and energy consumption evaluation // Bioresource Technology. 2010. Vol. 101. Pp. 4992-5002.

51. Патент № 64225 (Украина). Мобильная поточная линия гранулирования отходов / М.В. Коломийченко, А.М. Сисоев / 2011.

52. Bura R., Mansfield S.D., Saddler J.N., Bothast R.J. $\mathrm{SO}_{2}-$ catalyzed steam explosion of corn fiber for ethanol production // Appl Biochem Biotechnol. 2002. Vol. 98-100. Pp. 59-72.

53. Jin-Suk Lee, Binod Parameswaran, Lee Joon-Pyo, Park Soon-Chul. Recent developments of key technologies on cellulosic ethanol production // Journal of scientific \& Industrial Rescarch. 2008. Vol. 67. Pp. 865-873.

54. Carvalheiro F., Duarte L.C., Grio F.M. Hemicellulose biorefineries: a review on biomass pretreatments// Journal of Scientific \& Industrial Receach. 2008. Vol. 67. Pp. 849-864.

55. Zahoor, Yuanyuan Tu. Pretreatments to enhance the digestibility of wheat straw // International Journal of Renewable and Sustainable Energy. 2014. Vol. 3. N1. Pp. 26-34.

56. Galbe M., Zacch G.Pretreatment of Lignocellulosic materials for efficient bioethanol production // Advances in Biochemical Engineering Biotechnology. 2007. Vol. 108. Pp. 41-65.

57. Brodeur Gary, Yau Elizabeth, Badal Kimberly, Collier John, Ramachandran K.B., Ramakrishnan Subramanian. Chemical and physicochemical pretreatment of lignocellulosic biomass: A Review // Enzyme Research. 2011. Vol. 2011. $17 \mathrm{p}$.

58. Zhu J.Y., Zhuang X.S. Conceptual net energy output for biofuel production from lignocellulosic niomass through biorefining // Progress in Energy and Combusion Science. 2012. N38. Pp. 583-598.

59. Runcang, Lawther J.M., Banks W.B. Influence of alkaline pretreatments on the cell wall components of wheat straw // Industrial Crops and Products. 1995. Vol. 4. N2. Pp. 127-145.

60. Xuejun Pan, Xiao Zhang, David J. Gregg. Enhanced enzymatic hydrolysis of steam-exploded douglas fir wood by alkali-oxygen post-treatment // Applied Biochemistry and Biotechnology. 2004. Vol. 115. N1-3. Pp. 1103-1114.

61. Бебякова М.В., Киселева З.Л., Козлов Ю.П., Финкельштейн Б.Л., Чеховская В.Б. Применение щелочных и окислительно-щелочных обработок древесины сосны и березы для повышения эффективности ферментативного гидролиза полисахаридов // Химия древесины. 1989. №6. С. 84-88.

62. Wang Yang, Liu Shijie. Pretreament technologies for biological and chemical conversion of woody biomass // Tappy Journal. 2012. Vol. 11. N1. Pp. 9-15.

63. Lan T.Q., Gleisner Roland, Zhu J.Y., Duen S.B., Hector R.E. High titer ethanol production from SPORL-pretreated lodgepole pine by simultaneous enzymatic sacharification and combined fermentation // Bioresource Technology. 2013. Vol. 127. Pp. 291-297.

64. Pan Xuejun, Zhu Junyong. An update on sulfite pretreament of lignocellulosic biomass for effective production of cellulose ethanol // Proceeding of the 16 ISWFPC. Tianjin, 2011. Pp. 968-972. http://www.fpl.fs.fed.us/documnts/pdf2011/fpl_2011_pan001.pdf

65. Жуков Н.А., Синицын А.П., Быков В.А. и др. О повышении реакционной способности растительного сырья к ферментативному воздействию // Превращения древесины при энзиматическом и микробиологическом воздействиях: сб. научн. тр. Рига, 1985. С. 73-79.

Поступило в редакиию 22 сентября 2015 г. 
Sushkova V.I. ${ }^{1}$, Ustyjaninova L.V. ${ }^{2}$, Berezina O.V. ${ }^{1}$, Yarotsky S.V. ${ }^{l}$ METHODS OF PREPARING PLANT RAW MATERIAL FOR BIOCONVERSION IN FEED PRODUCTS AND ETHANOL

${ }^{1}$ State Scientific-Research Institute of Industrial Microorganisms Genetics and Breeding, 1st Dorozhny proezd, 1, Moscow, 117545 (Russia), e-mail: sushkovaval@mail.ru

${ }^{2}$ Vyatka State University, ul. Moscowskaya, 36, Kirov, 610000 (Russia)

An analysis of literature data the following preprocessing methods starch, pentosane- and cellulosic feedstock for enzymatic hydrolysis polysaccharides: hydrothermal, organosolvent obtaining technical cellulose, organosolvent with sulfuric acid, acid-catalyzed steam explosion, alkali, bisulfite (SPORL) and acid-catalyzed using a disk mill is presented.

Recommendations about improvement of technological schemes of obtaining fodder protein products of bran together with other grain waste are provided. Technological scheme should include additional process fine grinding of bran and grain waste and hydro-thermodynamic treatment (HTDO) at the next technological mode: a.d.s $\geq 15 \% ; \mathrm{t}=86-100{ }^{\circ} \mathrm{C}$; processing time $\leq 1 \mathrm{~h}$; using a thermostable $\alpha$-amylase (Zymajunt-340C* or Amylase HT-4000 or Amileks 4T). The effectiveness of a subsequent enzymatic hydrolysis of partially decomposed starch and non-starch polysaccharides of starchy raw material is ensured by the enzymatic complex including Glucoamylase, GC 220, containing cellulase, cellobiase, xylanase and $\beta$-glucanase activities, and Novozymes 188, containing cellobiase.

The most effective methods for preprocessing of pentosan - and cellulosic feedstock to enzymatic hydrolysis of cellulose in a $2 \%$ suspension of lignocellulosic residue are allow obtained an overall yield of sugars and ethanol at least $90 \%$ of the theoretical. The following preprocessing methods are considered to be as the most promising: organosolvent with $\mathrm{H}_{2} \mathrm{SO}_{4}$ and steam explosion with $\mathrm{SO}_{2}$ and the subsequent washing of the extruded biomass with water and oxidation-alkaline solution and mechanochemical: bisulfite (SPORL) and acid catalysis units with installation of hot grinding (IHG). It is established, that in the first two methods allowed the lignin content in the lignocellulose is to $16-18 \%$, and the third up to $30 \%$. Acid-catalyzed hydrolysis method with elements of SPORL technology with the use of installation hot grinding (IHG) is recommended for laboratory and experimental-industrial tests in the hydrolysis industry.

Cellulose from lignocellulosic residue is efficiently hydrolysed by Celluclast (20 FPU/g glucan), and Novozyme 188 ( $\beta$ glucosidase : cellulase 1,75-2,0:1) or Spezyme CP, GC-220 (15 FPU/g glucan), Multifect Xylanase ( $\beta$-glucosidase:cellulase 2,0:1).

Keywords: starchy raw materials, grain waste, pentosane- and cellulosic feedstock, polysaccharides, hemicelluloses, hemicelluloses hydrolysate, lignocellulosic residue, enzymatic hydrolysis, an enzyme; amylase, cellulase, csilananda activity; the degree of conversion, product yield, crude protein, stage of the technological scheme, material balance.

\section{References}

1. Iarotskii S.V., Sushkova V.I., Sineokii S.P., Lukina G.P. Ekonomicheskii analiz proizvodstva biobutanola i perspektivy ego razvitiia. [The economic analysis of bioethanol production and its development prospects]. Moscow, 2008, 65 p. (in Russ.).

2. Sushkova, V.I., Vorob'eva G.I. Bezotkhodnaia konversiia rastitel'nogo syr'ia v biologicheski aktivnye veshchestva. [Waste-free conversion of vegetable raw materials in biologically active substances]. Moscow, 2008, 215 p. (in Russ.).

3. Sushkova V.I., Ustiuzhaninova L.V. Metody podgotovki otkhodov proizvodstv lesopileniia $i$ derevoobrabotki $k$ biokonversii v biorastvoriteli. [Methods of preparation of the waste production sawmilling and wood to the bioconversion in biorastvoriteli]. Moscow, 2013, 95 p. (in Russ.).

4. Sushkova V.I., Ustiuzhaninova L.V. Obshchestvo, nauka, innovatsii (NTK-2011): vserossiiskaia nauchnotekhnicheskaia konferentsiia. [Society, science, innovation (SPC-2011): All-Russian Scientific and Technical Conference]. Kirov, 2014, pp. 20-23. (in Russ.).

5. Sharkov V.I., Sapotnitskii S.A., Dmitrieva O.A., Tumanov I.F. Tekhnologiia gidroliznykh proizvodstv. [Hydrolysis technology industries]. Moscow, 1973, 408 p. (in Russ.).

6. Sharkov V.I., Kuibina N.I. Khimiia gemitselliuloz. [Chemistry hemicellulose]. Moscow, 1972, 440 p. (in Russ.).

7. Khol'kin Iu.I. Tekhnologiia gidroliznykh proizvodstv. [Hydrolysis technology industries]. Moscow, 1989, 496 p. (in Russ.).

8. Sushkova V.I., Ustiuzhaninova L.V. Obshchestvo, nauka, innovatsii (NTK-2011): vserossiiskaia nauchnotekhnicheskaia konferentsiia. [Society, science, innovation (SPC-2011): All-Russian Scientific and Technical Conference]. Kirov, 2012, pp. 16-17. (in Russ.).

9. Likhtenberg L.A. Pishchevaia promyshlennost', Moscow, 1997, no. 3, pp. 22-25. (in Russ.).

10. Sushkova V.I. Protsess fermentatsii. Bioreaktory. Praktikum k kursovomu i diplomnomu proektirovaniiu. Uchebnoe posobie. [The fermentation. Bioreactors. Workshop to course and degree designing. Tutorial]. Kirov, 2006, 63 p. (in Russ.).

11. Ustiuzhaninova L.V., Sushkova V.I. Novye dostizheniia v khimii i khimicheskoi tekhnologii rastitel'nogo syr'ia. [New advances in chemistry and chemical technology of plant raw materials]. Barnaul, 2012, pp. 523-524. (in Russ.).

12. Patent 2478701 (RU), 2013. (in Russ.).

13. Patent 215287 (RU), 2000. (in Russ.).

14. Sinitsyn A.P., Gusakov A.V., Chernoglazov V.M. Biokonversiia lignotselliuloznykh materialov. [Bioconversion of lignocellulosic materials]. Moscow, 1995, 220 p. (in Russ.).

15. Dedkov V.N. Razrabotka biotekhnologii kormovogo belka iz rastitel'nogo syr'ia: dis. ... kand. tekhn. nauk. [Biotechnology Development feed protein from vegetable raw materials: Dis. ... Cand. tehn. sciences]. Voronezh, 2014,23 p. (in Russ.).

\footnotetext{
* Corresponding author.
} 
16. Guoce Yu., Shinichi Yano, Hiroyuki Inoue, Seiichi Inoue, Takashi Endo, Shigeki Sawayama. Applied Biochemistry and Biotechnology, 2010, vol. 160, no. 2, pp. 539-551.

17. Weil J.R., Sarikaya A., Rau Sh-L., Goetz J., Ladisch Ch.M., Brewer M., Hendrickson R., Ladisch M.R. Applied Biochemistry and Biotechnology, 1998, vol. 73, no. 1, pp. 1-17.

18. Lei H., Cybulska I., Julson J. Journal of Sustainable Bioenergy Systems, 2013, vol. 3, no. 4, pp. 250-259.

19. Harmsen P.F.H., Huijgen W.J.J., López L.M. Bermudez. Literature Review of Physical and Chemical Pretreatment Processes for Lignocellulosic Biomass. Preface. ECN-E--10-013. 2010. (Netherlands). [Electronic resource]. URL: http://www.ecn.nl/docs/library/report/2010/e10013.pdf

20. Vorob'eva G.I., Zaikina A.I., Sychev A.E. i dr. Perspektivnye fermentnye preparaty i biotekhnologicheskie protsessy $v$ tekhnologiiakh produktov pitaniia i kormov: sbornik nauchnykh trudov. [Promising enzyme preparations and biotechnological processes in technologies of food and feed: Proceedings]. Moscow, 2014, pp. 323-332. (in Russ.).

21. Sinitsyn A.P., Popov V.O., Sinitsyna O.A., Rozhkova A.M., Fedorova E.A., Morozova V.V., Zorov I.N., Gusakov A.V., Semenova M.V., Kondrat'eva E.G., Sattrutdinov A.L., Korotkova O.G., Osipov D.O., Bekkarevich A.O., Matys V.Iu., Bubnova T.V., Koshelev A.V., Okunev O.N. Vysokoeffektivnyi kompleks tselliulaz Penicillium dlia osakharivaniia lignotselliuloznoi biomassy. [Highly complex cellulases Penicillium for the saccharification of lignocellulosic biomass]. [Electronic resource]. URL: http://biorosinfo.ru/Vcongress/Sinizin.pdf

22. Morozov E.A., Riazanova T.V., Eremenko O.N. Molodye uchenye v reshenii aktual'nykh problem nauki: sb. nauchn. tr. [Young scientists in solving urgent problems of science: a collection of scientific papers]. 2010, vol. 2, pp. 39-43. (in Russ.).

23. Zang Meng, Song Xiiaoxu, Deines T.W., Pei Z.J., Wang Donghai. Journal of Biomedicine and Biotechnology, 2012, vol. 2012, 9 p.

24. Zhukov N.A. Teoreticheskie osnovy i tekhnologicheskie printsipy nepreryvnoi konversii rastitel'nogo sy-r'ia: avtoref. dis. ... d. tekhn. nauk. [The theoretical basis and technological principles of continuous conversion of vegetable raw materials: Abstract. Dis. ... Doctor of Technical Sciences]. Kirov, 2001, 45 p. (in Russ.).

25. Zhu J.Y. Tappi IBBC, 2011, 28 p.

26. Zhu J.Y., Wang G.S., Pan X.J., and et. al. Chemical Engineering Science, 2009, vol. 64, no. 3, pp. 474-485.

27. Goliazimova O.V. Mekhanicheskaia aktivatsiia fermentativnogo gidroliza tselliulozy i lignotselliuloznykh materialov: avtoref. dis. ... kand. khim. nauk. [Mechanical activation of the enzymatic hydrolysis of cellulose and lignocellulose materials: Abstract. Dis. ... Cand. Chem. sciences]. Novosibirsk, 2010, 20 p. (in Russ.).

28. Iakovlev M., Pääkkönen T., van Heiningen A. Holzforschung, 2009, vol. 63, pp. 779-784.

29. Germer E.I. Khimizm i kataliz kislorodno-shchelochnoi delignifikatsii: dis. ... dokt. khim. nauk. [The chemistry and catalysis, acid-alkaline delignification: dis. ... Doctor. Chem. sciences]. Sankt-Peterburg, 1999, 287 p. (in Russ.).

30. Sazhin A.A. Issledovanie fiziko-khimicheskikh protsessov delignifikatsii drevesiny $v$ sisteme etanol-voda-uksusnaia kislota i proluchenie materialov na osnove organosol'ventnykh polufabrikatov: dis. ... kand. tekhn. nauk. [The study of physical and chemical processes of delignification of wood in system ethanol-water-acetic acid and Translation of information received on the basis of materials organosolventnyh semis: dis. ... Cand. tehn. sciences]. Ioshkar-Ola, 2004, 20 p. (in Russ.).

31. Stockburger Pad. Tappi Journal, 1993, vol. 76, no. 6, pp. 70-74.

32. Engvist E. Ivpregnation, vapor phase and methanol as means of intensivying the softwood kraft pulping process: diss. ... doct. of science. Helsinki, Espoo, 2006.

33. Fam Van Koong. Natronnaia varka drevesiny sosny v sisteme izobutilovyi spirt - voda: avtoref. dis. ... kand. tekhn. nauk. [Soda pulping of pine wood in the system of isobutyl alcohol - water: Author. Dis. ... Cand. tehn. sciences]. Arkhangel'sk, 1995, 18 p. (in Russ.).

34. Patent 4767500 (US). 1988.

35. Black N.P. Tappi Journal, 1991, vol. 74, no. 4, pp. 129-132.

36. Patent 2135665 (RU). 1999. (in Russ.).

37. Pan X.J., Arato C., Gilkes N., Gregg David, Mabee Warren, Pye Kendall, Xiao Zhizhuang, Zhang Xiao, Saddler John. Biotechnology and Bioengineering, 2005, vol. 90, no. 4, pp. 473-481.

38. Beluza Ia.M. Destruktsiia tselliulozosoderzhashchikh materialov pri vozdeistvii sdvigovykh deformatsii $i$ vyso-kogo davleniia i tekhnologiia kormovykh dobavok: avtoref. dis. ... kand. tekhn. nauk. [Degradation of cellulose-containing materials when subjected to shear deformation and high-pressure technology and feed additives: Abstract. Dis. ... Cand. tehn. sciences]. Leningrad, 1987, 19 p. (in Russ.).

39. Mackie K.L., Brownell H.H., West K.L., Saddler N. Journal of Chemistry and Technology, 1985, no. 5(3), pp. 405-425.

40. Wyman C.E., Date D.E., Elander R.T. Biotechnology Progress, 2009, vol. 25, pp. 333-339.

41. Galbe M., Zacchi G. Appl Microbiol Biotechnol, 2002, vol. 59, pp. 618-628.

42. Mabee W.E., Grecc D.J., Arato C., Berlin A., Bura R., Gilkes N., Mirochnik O., Pan X., Pye E.K., Saddler J.N. Applied Biochemistry and Biotechnology, 2006, vol. 129, no. 1-3, pp. 55-70.

43. Yang B., Boussaid A., Mansfield S.D., Gregg D.J., Saddler J.N. Biotechnology and Bioengineering, 2002, vol. 77, pp. 678-684.

44. Wayman M., Parekh S., Chornet E. Biotechnology Letters, 1986, vol. 8, no. 10, pp. 749-752.

45. Ewanick S.M., Bura R., Saddler J.N. Biotechnology and Bioengineering, 2007, vol. 98, no. 4, pp. 737-746.

46. Ewanick S.M. Bioconversion of mountain pine beetle-killed lodgepole pine to ethanol. A thesis submitted in partial fulfillment of the requirements for the degree of master of science. 2006, $128 \mathrm{p}$. 
47. Clark T.A., Vackie K.L. Journal of Wood Chemistry and Technology, 1987, vol. 7, no. 3, pp. 373-403.

48. Boussaid A, Robinson J, Cai Yj and et. al. Biotechnol Bioeng. 1999, vol. 5, no. 64(3), pp. 284-289.

49. Boussaid A, Cai Y, Robinson J., Cai Y.J., Gregg D.J., Saddler J.N. Biotechnology Progress. 2001, vol. 17, no. 5, pp. 887-892.

50. Zhu J.Y., Pan X.J. Bioresource Technology. 2010, vol. 101, pp. 4992-5002.

51. Patent 64225 (UK). 2011. (in Russ.).

52. Bura R., Mansfield S.D., Saddler J.N., Bothast R.J. Appl Biochem Biotechnol. 2002, vol. 98-100, pp. 59-72.

53. Jin-Suk Lee, Binod Parameswaran, Lee Joon-Pyo, Park Soon-Chul. Journal of scientific \& Industrial Rescarch. 2008, vol. 67, pp. 865-873.

54. Carvalheiro F., Duarte L.C., Grio F.M. Journal of Scientific \& Industrial Receach. 2008, vol. 67, pp. 849-864.

55. Zahoor, Yuanyuan Tu. International Journal of Renewable and Sustainable Energy. 2014, vol. 3, no. 1, pp. $26-34$.

56. Galbe M., Zacch G. Advances in Biochemical Engineering Biotechnology. 2007, vol. 108, pp. 41-65.

57. Brodeur Gary, Yau Elizabeth, Badal Kimberly, Collier John, Ramachandran K.B., Ramakrishnan Subramanian. Enzyme Research. 2011, vol. 2011, 17 p.

58. Zhu J.Y., Zhuang X.S. Progress in Energy and Combusion Science. 2012, no. 38, pp. 583-598.

59. Runcang, Lawther J.M., Banks W.B. Industrial Crops and Products. 1995, vol. 4, no. 2, pp. 127-145.

60. Xuejun Pan, Xiao Zhang, David J. Gregg. Applied Biochemistry and Biotechnology. 2004, vol. 115, no. 1-3, pp. 1103-1114.

61. Bebiakova M.V., Kiseleva Z.L., Kozlov Iu.P., Finkel'shtein B.L., Chekhovskaia V.B. Khimiia drevesiny. 1989, no. 6, pp. 84-88. (in Russ.).

62. Wang Yang, Liu Shijie. Tappy Journal. 2012, vol. 11, no. 1, pp. 9-15.

63. Lan T.Q., Gleisner Roland, Zhu J.Y., Duen S.B., Hector R.E. Bioresource Technology. 2013, vol. 127, pp. $291-297$.

64. Pan Xuejun, Zhu Junyong. Proceeding of the 16 ISWFPC. Tianjin, 2011, pp. 968-972. http://www.fpl.fs.fed.us/documnts/pdf2011/fpl_2011_pan001.pdf

65. Zhukov N.A., Sinitsyn A.P., Bykov V.A. i dr. Prevrashcheniia drevesiny pri enzimaticheskom i mikrobiologicheskom voz-deistviiakh: sb. nauchn. tr. [Transformation of wood with enzymatic and microbiological effects: a collection of scientific papers]. Riga, 1985, pp. 73-79. (in Russ.). 
